\title{
Lipoprotein(a) Lowering-From Lipoprotein Apheresis to Antisense Oligonucleotide Approach
}

\author{
Maria Francesca Greco ${ }^{1} \mathbb{D}$, Cesare R. Sirtori ${ }^{2}$, Alberto Corsini ${ }^{1,3}$, Marat Ezhov ${ }^{4}(\mathbb{D}$, \\ Tiziana Sampietro ${ }^{5}$ and Massimiliano Ruscica ${ }^{1, * \mathbb{D}}$ \\ 1 Dipartimento di Science Farmacologiche e Biomolecolari, Università degli Studi di Milano, \\ 20133 Milan, Italy; mariafrancesca.greco@unimi.it (M.F.G.); alberto.corsini@unimi.it (A.C.) \\ 2 Dyslipidemia Center, A.S.S.T. Grande Ospedale Metropolitano Niguarda, 20162 Milan, Italy; \\ cesare.sirtori@icloud.com \\ 3 IRCCS Multimedica, 20099 Milan, Italy \\ 4 National Medical Research Center of Cardiology of the Ministry of Health, Moscow, Russia; \\ marat_ezhov@mail.ru \\ 5 U.O. Lipoapheresis and Center for Inherited Dyslipidemias, Fondazione Toscana Gabriele Monasterio, \\ 56126 Pisa, Italy; tiziana.sampietro@ftgm.it \\ * Correspondence: massimiliano.ruscica@unimi.it; Tel.: +39-0250318220
}

Received: 13 June 2020; Accepted: 1 July 2020; Published: 3 July 2020

\begin{abstract}
It is well-known that elevated lipoprotein(a) — L p (a) — levels are associated with a higher risk of cardiovascular (CV) mortality and all-cause mortality, although a standard pharmacotherapeutic approach is still undefined for patients with high CV risk dependent on hyperlipoproteinemia(a). Combined with high Lp(a) levels, familial hypercholesterolemia (FH) leads to a greater CVD risk. In suspected $\mathrm{FH}$ patients, the proportion of cases explained by a rise of $\mathrm{Lp}(\mathrm{a})$ levels ranges between $5 \%$ and $20 \%$. In the absence of a specific pharmacological approach able to lower $\mathrm{Lp}(\mathrm{a})$ to the extent required to achieve CV benefits, the most effective strategy today is lipoprotein apheresis (LA). Although limited, a clear effect on Lp(a) is exerted by PCSK9 antagonists, with apparently different mechanisms when given with statins (raised catabolism) or as monotherapy (reduced production). In the era of RNA-based therapies, a new dawn is represented by the use of antisense oligonucleotides $\mathrm{APO}(\mathrm{a}) \mathrm{L}_{\mathrm{rx}}$, able to reduce $\mathrm{Lp}(\mathrm{a})$ from $35 \%$ to over $80 \%$, with generally modest injection site reactions. The improved knowledge of $\mathrm{Lp}(\mathrm{a})$ atherogenicity and possible prevention will be of benefit for patients with residual CV risk remaining after the most effective available lipid-lowering agents.
\end{abstract}

Keywords: lipoprotein(a); lipoprotein apheresis; statins; niacin; proprotein convertase subtilisin/kexin type 9; antisense oligonucleotide $\mathrm{APO}(\mathrm{a}) \mathrm{L}_{\mathrm{rx}}$

\section{Introduction-An Overview}

In the last decade, an awareness of the association between cardiovascular (CV) risk and elevated levels of lipoprotein(a) [Lp(a)] has emerged from both epidemiological and genetic studies [1-3] and led to the need to improve treatments for patients with atherosclerotic cardiovascular disease (ASCVD), as therapeutic approaches able to lower $\mathrm{Lp}(\mathrm{a})$ levels to the extent required to achieve a CV benefit are missing. Lipoprotein apheresis (LA) is still a potentially valuable therapeutic approach in the case of hyperlipoproteinemia(a) [4]. $\mathrm{Lp}(\mathrm{a})$ is the product of the covalent binding by the disulfide bond of apolipoprotein (apo)B (largely hydrophobic) to the plasminogen-like glycoprotein apo(a) (largely hydrophilic) in a 1:1 molar ratio $[5,6]$. Both apoB and apo(a) represent $80 \%$ of $\mathrm{Lp}(\mathrm{a})$ proteome, with 35 additional proteins that play roles from lipid metabolism to wound-healing, to immunity [7].

Clinical conditions resulting in raised CV risk are particularly stimulating, in order to improve choices for handling Lp(a) elevations. Familial hypercholesterolemia (FH) and elevated Lp(a) are a 
double heritable risk [8], i.e., carriers of a receptor-negative mutation in the low-density lipoprotein receptor (LDLR) gene with high $\mathrm{Lp}(\mathrm{a})(>50 \mathrm{mg} / \mathrm{dL})$ show a higher cardiovascular disease (CVD) risk compared to patients with the same mutation and Lp(a) levels $<50 \mathrm{mg} / \mathrm{dL}$ [9]. In suspected FH patients, the proportion of cases explained by biochemical evaluation of $L p(a)$ is between $5 \%$ and $20 \%$. Genetically driven high levels of Lp(a) can raise LDL-cholesterol (LDL-C) and, independently, the risk of CVD [10]. Elevated levels of Lp(a) have been observed in FH patients, i.e., two- to three-fold, compared with controls matched for kringle IV 2 (KIV-2) copy number variation. Data from 46,200 Danish individuals showed that $25 \%$ of FH receive this diagnosis due to their high Lp(a) concentrations [11]. However, the mechanism behind the elevation of $L p(a)$ in FH is still unclear. Considering the hypothesis that $\mathrm{Lp}(\mathrm{a})$ may be catabolized by the low-density lipoprotein receptor (LDLR) pathway, Lp(a) levels rise with the number of LDLR mutations, consistent with a positive gene dosage effect [12]. However, the hypothesis of Lp(a) clearance through the LDLR has been challenged recently. No differences in $\mathrm{Lp}(\mathrm{a})$ levels were found between carriers of pathogenic variants of $L D L R$ and $A P O B$ vs. noncarriers [13].

The uncertainties regarding the strategy to handle elevated $\mathrm{Lp}(\mathrm{a})$, particularly in patients with concomitant hypercholesterolemia, have paved the way to review the present-day evidence on the role of elevated Lp(a) in this high-risk condition, as well as on the relative value of different therapeutic approaches, i.e., from LA to upcoming RNA-based therapeutics.

Lp(a) levels are controlled mostly genetically by the LPA gene locus, characterized by an extensive size polymorphism of apo(a) caused by a variable number of different KIV-2 repeats. The size of $\mathrm{Lp}(\mathrm{a})$ is very broad, ranging from 300 to $800 \mathrm{kDa}$. The extensive polymorphic nature of the apo(a) gene size makes homozygotes of apo(a) size rare, whereas heterozygosity is at approximately $94 \%$ among Caucasians [14]. Individuals with small apo(a) isoforms have higher median levels of Lp(a) compared to individuals carrying large apo(a) isoforms. However, KIV-2 copy number variations alone explain 19-77\% of the variation in $L p(a)$ levels [15]. Levels of $L p(a)$ vary among individuals of different ethnicities, with the African ethnicity having higher levels compared to the European and Asian ethnicities [16]. These observations are to be combined with the difficulties in establishing a generally accepted mode of measurement [17]. First of all, available assays report results in mass $(\mathrm{mg} / \mathrm{dL})$ instead of concentration in $\mathrm{nmol} / \mathrm{L}$, and a direct conversion may not be possible because of the variable number of repeated units in different apo(a) isoforms. Secondly, absolute differences in $\mathrm{Lp}(\mathrm{a})$ measurements for single samples have been reported as up to almost $80 \mathrm{mg} / \mathrm{dL}$ [18]. Third, Lp(a) values vary if samples used are fresh or have been frozen for prolonged periods of time.

\section{Cardiovascular (CV) Risk Associated with Lipoprotein (a) Levels}

The CV risk of elevated Lp(a) still remains an open question [19], in particular because of the unsettled definition of levels requiring treatment. Among the general population, $\mathrm{Lp}(\mathrm{a})$ concentrations have a more than 1000 -fold interindividual range", with a prevalence of $35 \%$ for values $>30 \mathrm{mg} / \mathrm{dL}$, $20 \%$ for values $>60 \mathrm{mg} / \mathrm{dL}, 10 \%$ for values $>90 \mathrm{mg} / \mathrm{dL}, 5 \%$ for values $>116 \mathrm{mg} / \mathrm{dL}$ and $1 \%$ for values $>180 \mathrm{mg} / \mathrm{dL}$ [20]. Data from a Mendelian randomization analysis indicated that the Lp(a)-lowering therapeutic effect size [to reduce CAD risk in a similar way to a reduction of $38.7 \mathrm{mg} / \mathrm{dL}(1 \mathrm{mmol} / \mathrm{L})$ ] of LDL-C should be roughly $100 \mathrm{mg} / \mathrm{dL}$ (2.6 nmol/L) [21]. This conclusion was not supported by other authors who replicated a similar approach, not considering, however, Lp(a)-elevating single-nucleotide polymorphisms (SNPs), but based on 13,781 individuals with median Lp(a) levels in a range typical of Caucasian populations. By this approach, it was calculated that an $\mathrm{Lp}$ (a) lowering of $65.7 \mathrm{mg} / \mathrm{dL}$ would be required in order to achieve a similar CV benefit as that attained by the $38.7 \mathrm{mg} / \mathrm{dL}$ reduction of LDL-C [22]. The above quoted value of $101.5 \mathrm{mg} / \mathrm{dL}$ [21] was likely overestimated, being based on patients with median $\mathrm{Lp}(\mathrm{a})$ concentrations two-fold to three-fold higher than the median levels found in the same ethnicity [23]. However, as elsewhere described, it cannot be overlooked that the analysis by Burgess et al. [21] included studies in which $\mathrm{Lp}(\mathrm{a})$ levels were lower than those defined as a treatment criterion for LA [24]. Finally, in the debate regarding whether or not high Lp(a) leads to 
recurrent CVD events, a population study concluded that in secondary prevention, an Lp(a) lowering by $50 \mathrm{mg} / \mathrm{dL}$ (approximately $105 \mathrm{nmol} / \mathrm{L}$ ) over a period of 5 years is needed to reduce CVD events by $20 \%$ [25].

While an optimal Lp(a) level $<50 \mathrm{mg} / \mathrm{dL}$ was previously reported in Europe [26], the 2018 American Guidelines suggested the measurement of $\mathrm{Lp}(\mathrm{a})$ in people with a familial or personal history of premature atherosclerotic CVD that were not explained by major risk factors [27]. The 2019 European Society of Cardiology (ESC)/European Atherosclerosis Society (EAS) Guidelines for the management of dyslipidemias have recommended $L p(a)$ measurement at least once in each adult person's lifetime, with the objective of identifying those with very high inherited $L p(a)$ levels (>180 mg/dL) [28]. Nowadays, since $\mathrm{Lp}(\mathrm{a})$ levels remain stable throughout one's life outside of acute illness, it seems there is not much role for serial measurement (cited in [17]). However, the value of $180 \mathrm{mg} / \mathrm{dL}$ has not been indicated as a threshold for Lp(a) risk, but rather as conveying a CVD-risk comparable to that of heterozygous familial hypercholesterolemia (HeFH). Thus, although the value of $>50 \mathrm{mg} / \mathrm{dL}$-representing the 80th percentile of the Caucasian population - has been proposed as a tentative universal cut-off point [17], it remains a topic of debate among many experts in the lipid community [20]; while Lp(a) $\geq$ $50 \mathrm{mg} / \mathrm{dL}$ best predicted cardiovascular heart disease in the Caucasians, the Chinese-Americans and the Hispanics, the corresponding value for those of African ethnicity was $30 \mathrm{mg} / \mathrm{dL}$ [29]. A further challenge on this issue came from the genetic evidence linking high $L p(a)$ levels to the development of CVD, i.e., a stepwise increment in the Hazard Ratio (HR; from 1 to 2.6) was reported, starting between $\mathrm{Lp}(\mathrm{a})<5 \mathrm{mg} / \mathrm{dL}$ and $\mathrm{Lp}(\mathrm{a})>117 \mathrm{mg} / \mathrm{dL}$ [2].

In the case of $\mathrm{FH}$ patients carrying high levels of $\mathrm{Lp}(\mathrm{a})$, the mechanism beneath the increased risk may also act in the additive risk of the inhibition of fibrinolysis [30], as suggested by the seminal idea by Brown and Goldstein [31]. This and other hypotheses have never been proven, but have led to a number of contrasting studies, with some authors indicating a very high CV risk, and others not $[32,33]$. The measurement of "LDL-cholesterol" contains the cholesterol content of both LDL and the LDL component of Lp(a) [11], since each Lp(a) particle is composed of about 30-45\% cholesterol. Interestingly, for a similar cholesterol content increase of Lp(a) and LDL (15 mg/dL; $0.39 \mathrm{mmol} / \mathrm{L}), \mathrm{Lp}(\mathrm{a})$ cholesterol is more strongly associated with CV mortality; HR 1.18 (1.12-1.25) vs. 1.05 (1.04-1.07), respectively. A similar conclusion was reached in the case of all-cause mortality: HR 1.07 (1.04-1.10) for Lp(a) cholesterol and HR 1.01 (1.00-1.01) for LDL-C [34]. This evidence implies that both cholesterol content and the atherogenic nature of the apolipoprotein can be responsible for the increased risk [34,35]. Adjusting LDL-C concentration for Lp(a)-C improves the diagnostic accuracy of the Dutch Lipid Clinic Network and Simon Broome criteria, especially for patients with $\mathrm{Lp}(\mathrm{a})>100 \mathrm{mg} / \mathrm{dL}$ and LDL-C $<251$ $\mathrm{mg} / \mathrm{dL}$ [36]. All-in-all, this evidence leads to the general suggestion of a priority screening of all $\mathrm{FH}$ patients for high $\mathrm{Lp}(\mathrm{a})$ [37]

The importance of dosing Lp(a) in FH patients was corroborated by Langsted et al. [11], reporting that the HR for myocardial infarction (MI), which is 1 for the individuals who are unlikely to have FH and $\mathrm{Lp}(\mathrm{a})<50 \mathrm{mg} / \mathrm{dL}$, rises to 1.4 in individuals who are likely to have $\mathrm{FH}$ and $\mathrm{Lp}(\mathrm{a})>50 \mathrm{mg} / \mathrm{dL}$, then to 3.2 in those with possible, probable or definite $\mathrm{FH}$, and $\mathrm{Lp}(\mathrm{a})<50 \mathrm{mg} / \mathrm{dL}$, and finally to 5.3 in those with possibe or definite $\mathrm{FH}$ and $\mathrm{Lp}(\mathrm{a})>50 \mathrm{mg} / \mathrm{dL}$. More recently, in a large series of patients entering a Coronary Care Unit, evaluated using the same criteria, hyperlipoproteinemia(a) and FH were identified in $27 \%$ and $11.6 \%$ of individuals (vs. $4.4 \%$ of carriers of both disorders). Specifically, the risk of premature coronary artery disease was increased 1.9-fold when Lp(a) was considered, 3.2-fold in the case of FH phenotype, and 5.3-fold when both disorders were evaluated in combination [38]. An Italian and Swedish series showed that elevated Lp(a) significantly contributed to the raised CV risk in patients with a genomic diagnosis of FH [39]. It seems that FH does not cause hyperlipoproteinemia(a), but that a rise in $\mathrm{Lp}(\mathrm{a})$ increases the probability that an individual with genetic FH will be clinically recognized [13].

Although not in the scope of this review article, in addition to coronary artery disease [40], a raised incidence of aortic valve stenosis and coronary artery calcification has also been described in association 
with elevated Lp(a) [41-44]. As reviewed elsewhere [45,46], Lp(a) can exacerbate pathophysiological processes in calcific aortic disease, a progressive disorder that impairs the valve motion and restricts the ventricular outflow. Evidence also supports a causal association between $L p(a)$ and valve calcification.

\section{Statins}

Statins do not generally lower $\mathrm{Lp}(\mathrm{a})$ and may potentially raise $\mathrm{Lp}(\mathrm{a})$, although this trend seems confined to patients with a low molecular weight apo(a) phenotype [47]. A meta-analysis [48] involving 5256 patients (1271 on placebo and 3885 on different statins) from six randomized trials showed a difference in the statin vs. placebo pooled analysis, expressed as a geometric mean ratio of 1.11 (1.07-1.14). The mean changes from baseline ranged from $+11.6 \%$ to $+20.4 \%$ in the pravastatin group, and from $+18.7 \%$ to $+24.2 \%$ in the atorvastatin group. The authors also tested the effects of incubating HepG2 hepatocytes with atorvastatin, and reported a dose- and time-dependent increased expression of LPA mRNA, and synthesis and secretion of apo(a) protein [48]. Pirillo and Catapano [49] suggested that the underlying mechanism may relate to the reduction of intracellular cholesterol on the liver $X$ receptor-farnesoid X receptor (LXR-FXR) axis, since an FXR-responsive element is located within the promoter of the LPA gene [50]. In a follow-up comment, Banach and Penson [51] noted that most of the listed trials had mean $\mathrm{Lp}(\mathrm{a})<30 \mathrm{mg} / \mathrm{dL}$, and thus, although some of the reported rises were up to $101 \mathrm{mg} / \mathrm{dL}$, in most cases these changes may not have been clinically relevant. Specifically, in subjects with $L p(a) \geq 30-50 \mathrm{mg} / \mathrm{dL}$ in the statin group, the mean absolute $\mathrm{Lp}(\mathrm{a})$ change was $18.1 \mathrm{mg} / \mathrm{dL}$, whereas in those with $\mathrm{Lp}(\mathrm{a}) \geq 50 \mathrm{mg} / \mathrm{dL}$, the mean absolute change was $10.3 \mathrm{mg} / \mathrm{dL}$ [52].

Another mechanism has been hypothesized by Ma et al. [53]. In statin-treated patients, the fractional turnovers of apo(a) and apoB proteins within $L p(a)$ are similar, thus reflecting a tight coupling of these protein components. A recent kinetic study relative to the production rate of $\mathrm{Lp}(\mathrm{a})$ suggested that the hepatic availability of apoB is unlikely to be rate-limiting for the assembly and production of Lp(a) particles [54]. Overall, the molecular mechanisms responsible for Lp(a) catabolism still remain elusive, with several receptor systems being proposed as implicated in this process (lipoprotein receptors, toll-like and scavenger receptors, lectins, and plasminogen receptors) [55].

In a recent individual-patient meta-analysis of 29,069 patients from seven randomized controlled trials (RCTs) with statins, both baseline and on-statin $\mathrm{Lp}(\mathrm{a})$ concentrations were associated with an almost linear association with increment in CVDs, particularly for patients with Lp(a) concentrations of $50 \mathrm{mg} / \mathrm{dL}$ or higher, and those on statin therapy [56]. Thus, it is reasonable to use caution in the use of statins in patients with significant Lp(a) elevations, although the LDL-C lowering effect will most likely prevail in terms of CV prevention (Table 1). 
Table 1. Impact of synthetic lipid-lowering drugs on lipoprotein(a) levels.

\begin{tabular}{|c|c|c|}
\hline Drug & Study & Lp(a) ${ }^{1}$ Changes \\
\hline \multirow[t]{2}{*}{ Statin } & $\begin{array}{l}5256 \text { patients ( } 1271 \text { on placebo and } 3885 \\
\text { on different statins) from six randomized } \\
\text { trials [52] }\end{array}$ & $\begin{array}{l}\text { from }+11.6 \% \text { to }+20.4 \% \text { (pravastatin group) } \\
\text { from }+18.7 \% \text { to }+24.2 \% \text { (atorvastatin group) } \\
\text { mean absolute increase was } 18.1 \mathrm{mg} / \mathrm{dL} \text { in the } \\
\text { group with } \mathrm{Lp}(\mathrm{a}) \geq 30-50 \mathrm{mg} / \mathrm{dL} \\
\text { mean absolute increase was } 10.3 \mathrm{mg} / \mathrm{dL} \text { in the } \\
\text { group with } \mathrm{Lp}(\mathrm{a}) \geq 50 \mathrm{mg} / \mathrm{dL}\end{array}$ \\
\hline & JUPITER $^{2}$ (rosuvastatin $20 \mathrm{mg} / \mathrm{d}$ ) [57] & $\begin{array}{l}\text { The median change in } \mathrm{Lp}(\mathrm{a}) \text { with } \\
\text { rosuvastatin and placebo was zero } \\
\text { Placebo arm: median ( } 25 \text { th and } 75 \text { th) was } \\
23 \mathrm{nmol} / \mathrm{L}(10-48) \\
\text { Rosuvastatin arm: median ( } 25 \text { th and } 75 \text { th) } \\
\text { was } 24 \mathrm{nmol} / \mathrm{L}(10-51)\end{array}$ \\
\hline \multirow{6}{*}{ Nicotinic acid } & Hyperlipidemic patients [58] & $-38 \%$ (95\% CI $28-47 \%)$ \\
\hline & $\begin{array}{l}\text { Hyperlipidemic patients with Lp(a) } \\
\text { concentrations } \geqslant 18 \mathrm{mg} / \mathrm{dL} \text { [59] }\end{array}$ & from $-27.0 \pm 5.4$ to $-20.6 \pm 4.1$ \\
\hline & $\begin{array}{l}\text { Normolipidemic patients with coronary } \\
\text { artery disease [60] }\end{array}$ & $-21 \%$ \\
\hline & $\begin{array}{l}\text { Patients with type II hyperlipidaemia and } \\
\text { plasma } \mathrm{Lp}(\mathrm{a}) \text { concentration } \geq 30 \mathrm{mg} / \mathrm{dL} \\
{[61]}\end{array}$ & $-36.4 \%$ \\
\hline & HPS2-THRIVE ${ }^{3}$ [62] & $\begin{array}{l}\mathrm{Lp}(\mathrm{a}) \text { mean reduction of } 12.2 \mathrm{nmol} / \mathrm{L} \text {, which } \\
\text { became } 33.8 \mathrm{nmol} / \mathrm{L} \text { in the group with } \mathrm{Lp}(\mathrm{a}) \\
\text { baseline levels } \geq 128 \mathrm{nmol} / \mathrm{L}\end{array}$ \\
\hline & $\begin{array}{l}\text { Patients with different baseline Lp(a) } \\
\text { concentrations [63] }\end{array}$ & $\begin{array}{l}-19.2 \% \pm 3.7 \% \text { if } \mathrm{Lp}(\mathrm{a}) \text { was }<50 \mathrm{mg} / \mathrm{dL} \\
-20.7 \% \pm 5.4 \% \text { if } \mathrm{Lp}(\mathrm{a}) \text { was between } 50 \text { and } \\
120 \mathrm{mg} / \mathrm{dL} \\
-29.5 \% \pm 2.2 \% \text { if } \mathrm{Lp}(\text { a was }>120 \mathrm{mg} / \mathrm{dL})\end{array}$ \\
\hline
\end{tabular}

${ }^{1} \mathrm{Lp}(\mathrm{a})$, lipoprotein(a); ${ }^{2}$ JUPITER, Justification for the Use of Statins In Primary Prevention; ${ }^{3}$ HPS2-THRIVE, Treatment of HDL to Reduce the Incidence of Vascular Events HPS2-THRIVE.

\section{Nicotinic Acid}

This somewhat obsolete lipid-lowering agent was the first one to provide convincing data on a potential $\mathrm{Lp}(\mathrm{a})$ lowering effect. Prominent in this area was the study by Chennamsetty et al., demonstrating that feeding transgenic-APOA mice $1 \%$ nicotinic acid (NA) reduced plasma APOA and hepatic expression of APOA [64]. Moving to humans, the Swedish group headed by Carlson indicated a decrease of $38 \%$ (95\% CI 28-47\%) in 31 consecutive hyperlipidemic patients treated with 4-6 g/day for 6 weeks [58]. A similar activity was reported with $\alpha$-tocopheryl nicotinate [59], whereas a lesser activity effect $(-21 \%)$ was reported with niceritrol, an ester containing four nicotinic acid (NA) residues, and which was somewhat better tolerated [60].

In order to assess the mechanisms beneath $\mathrm{Lp}$ (a) reduction, Seed et al. [61] tested NA (1 g t.i.d.) in patients with elevated $L p(a)$ levels. An impressive $36.4 \% \mathrm{Lp}(\mathrm{a})$ reduction was found without any impact on $L p(a)$ catabolism. This indicated the major activity of NA on $L p(a)$ synthesis (Table 1 ). The authors also tested acipimox, a more powerful anti-lipolytic agent with better tolerability, but found no activity on $\mathrm{Lp}(\mathrm{a})$.

In more recent years, the combination of NA with laropiprant, a selective antagonist of the PGD2-receptor subtype-1, was extensively investigated. A sub-analysis of the HPS2-THRIVE study showed that, at 1 year, allocation to niacin-laropiprant resulted in an overall $\mathrm{Lp}$ (a) mean reduction of $12.2 \mathrm{nmol} / \mathrm{L}$, which became $33.8 \mathrm{nmol} / \mathrm{L}$ in the group with $\mathrm{Lp}$ (a) baseline levels $\geq 128 \mathrm{nmol} / \mathrm{L}$. Overall, the percentage reduction was $31(95 \%$ CI $28-33 \%)$, attenuating to $36 \%$ and $18 \%$ across quintiles by increasing baseline [62]. Overall, patients who may benefit the most were those with small isoform 
sizes and highest baseline $\mathrm{Lp}(\mathrm{a})$ levels. The $\mathrm{Lp}(\mathrm{a})$ reduction with this combination was confirmed in patients with an established Lp(a) genotype (OMIM 152200) [63]. While the data showed an inverse correlation between baseline Lp(a) concentrations and LPA genotype, there was no clear difference in the $\mathrm{Lp}(\mathrm{a})$-lowering activity of the NA-laropiprant association (mean around $25 \%$ ) in the different genotypes.

Recently, the addition of PCSK9 inhibitors to a background of niacin has been associated with a roughly $15 \%$ reduction in $\mathrm{Lp}(\mathrm{a})$ beyond that achieved with niacin monotherapy [65].

\section{PCSK9 Inhibitors}

The growing use of PCSK9 inhibitors has raised the question whether they reduce Lp(a) to such an extent that enables the CV benefits linked to Lp(a)-lowering [66,67]. Although PCSK9 inhibitors overall reduce $\mathrm{Lp}$ (a) by a mean of $20 \%$ (Table 2), the mechanisms beneath $\mathrm{Lp}$ (a) reduction are uncertain [68]. They range from a key role of the LDLR in Lp(a) catabolism to a reduced Lp(a) synthesis. Recently, a further mechanism has been hypothesized, i.e., Very-Low-Density Lipoprotein (VLDL)-apoE production could influence Lp(a) production and/or assembly [69]. Epidemiological studies have shown differences in plasma Lp(a) concentrations between apoE genotypes based on the three major E isoforms $(\varepsilon 2 / \varepsilon 3 / \varepsilon 4)$ [70]. Finally, although not strictly related to PCSK9 inhibition, an important contribution to $\mathrm{Lp}(\mathrm{a})$ release has come from Ma et al., reporting that the production rate of apo(a) is raised in subjects with elevated $\mathrm{Lp}(\mathrm{a})$, compared to those with normal levels, with no differences in apo(a) fractional catabolic rate between high and low Lp(a) groups [53]. Thus, elevated plasma $\mathrm{Lp}(\mathrm{a})$ concentration appears to be a consequence of the increased hepatic production of $\mathrm{Lp}(\mathrm{a})$ particles [53].

Relative to the clinical data, evolocumab results in significant dose-related reductions in Lp(a). With this agent, the mean percentage reduction was larger in patients with baseline Lp(a) of $\leq$ $125 \mathrm{nmol} / \mathrm{L}$, whereas the absolute reduction was higher in those with $>125 \mathrm{nmol} / \mathrm{L}$ [71]. Lp(a) reductions may be achieved by two different mechanisms: when given as monotherapy, evolocumab reduces the production rate of $\mathrm{Lp}(\mathrm{a})$, not the fractional catabolic rate (FCR) [72]; when administered in combination with atorvastatin, the FCR of $\mathrm{Lp}$ (a) rises significantly, without alterations of the production rate. Concerning alirocumab, a reduction of plasma $\mathrm{Lp}(\mathrm{a})$ levels $(-18.7 \%)$ has been reported and associated with the trend of an increased median FCR for Lp(a), and no change in the production rate [73]. The same conclusions have been reached by Watts et al. [74], reporting that in ASCVD patients with elevated Lp(a) [mean Lp(a) mass $180 \mathrm{mg} / \mathrm{dL}$ ] and on statins, alirocumab lowers plasma apo(a) pool size and raises the FCR of apo(a) without affecting apo(a) production rate.

The impact of PCSK9 antagonism on Lp(a) levels has also been confirmed by genetic analysis. Among carriers of Y142X ( $r$ s67608943) and C679X ( $r$ 28362286) of the REGARDS study, median Lp(a) levels were $63.2 \mathrm{nmol} / \mathrm{L}$ in carriers, compared to $80.4 \mathrm{nmol} / \mathrm{L}$ in non-carriers, respectively [75]. One hypothesis linking PCSK9 and Lp(a)-lowering may rely on the dramatic LDL-C reduction driven by PCSK9 inhibition. This could reduce a possible competitor for the binding to the LDLR, although targeted studies did not clearly indicate an involvement of the LDLR in Lp(a) uptake [76]. Although not supported by in vitro data, it might also be possible to hypothesize a direct binding between PCSK9 and Lp(a) [77,78]. Interestingly, after treatment with an anti-Lp(a) antibody, total PCSK9 levels did not change, whereas there was a steady decrement in PCSK9 bound to Lp(a) [PCSK9-Lp(a)] [79]. However, since only 1 out of $175 \mathrm{Lp}$ (a) particles binds to PCSK9, this would represent a very small percentage of total $\mathrm{Lp}(\mathrm{a})$ that is complexed [80]. Moreover, a study by our group showed that, irrespective of the presence of Lp(a), the analysis of PCSK9 lipoprotein distribution by Fast Protein Liquid Chromatography (FPLC) is not affected [81].

In a pre-specified analysis of the ODISSEY OUTCOMES Trial, $\mathrm{Lp}(\mathrm{a})$ levels were monitored at randomization and at 4 and 12 months [82]. The authors evaluated total Lp(a) changes vs. LDL-C corrected, and also non-LDL-C corrected at baseline. This approach allowed the identification of the real effect on $\mathrm{Lp}(\mathrm{a})$ reduction. Median relative and absolute changes from baseline to month 4 
were $-23 \%$ and $-5.0 \mathrm{mg} / \mathrm{dL}$, respectively. In patients with $\mathrm{Lp}$ (a) baseline $<6.7 \mathrm{mg} / \mathrm{dL}$ (quartile 1; Q1), essentially no changes in $\mathrm{Lp}$ (a) were found, whereas at month $4,80 \%$ of the patients in the other quartiles showed reductions. In the upper quartile $(\geq 59.6 \mathrm{mg} / \mathrm{dL})$, reductions were most significant $(-20.2 \mathrm{mg} / \mathrm{dL})$ and correlated with changes in LDL-C, both corrected and non-corrected. The reduction of Lp(a), also when corrected for LDL-C, independently predicted a lower risk of major adverse cardiovascular events (MACE). Lp(a) strata were $<6.7 \mathrm{mg} / \mathrm{dL}$ (Q1), from $6.7 \mathrm{mg} / \mathrm{dL}$ to $21.2 \mathrm{mg} / \mathrm{dL}$ (Q2), from $21.2 \mathrm{mg} / \mathrm{dL}$ to $<59.6 \mathrm{mg} / \mathrm{dL}$ (Q3), and $\geq 59.6 \mathrm{mg} / \mathrm{dL}$ (Q4). According to this distribution, the HR relative to MACE and the number-needed-to-treat (NNT) were $0.95(0.79-1.15)$ and 238 for Q1; $0.85(0.71-1.03)$ and 69 for Q2; $0.79(0.66-0.94)$ and 43 for Q3; $0.83(0.70-0.98)$ and 49 for Q4 [82]. Overall, a 1-mg/dL reduction of Lp(a) with alirocumab was associated with an $\mathrm{HR}$ of $0.994(95 \% \mathrm{CI}$, $0.990-0.999 \%$ ), thus allowing us to conclude that the risk-reduction associated with Lp(a) lowering was of the same order of magnitude as LDL-C on a per $\mathrm{mg} / \mathrm{dL}$ basis [83]. The ODISSEY OUTCOMES trial also reported that in patients with acute coronary syndrome, alirocumab reduced the occurrence of peripheral artery diseases according to the magnitude of $L p(a)$ lowering. One $\mathrm{mg} / \mathrm{dL}$ change in $\mathrm{Lp}$ (a) levels corresponded to a HR for peripheral artery disease or venous thromboembolism of 0.991 $(0.982-1.000 ; p=0.04)$.

Overall, the same conclusions were reached in the FOURIER trial [84]. Evolocumab given for 48 weeks significantly reduced $\mathrm{Lp}$ (a) by a median of $26.9 \%$. This percentage was correlated to that of LDL-C at the same interval ( $\mathrm{r}=0.37 ; 95 \% \mathrm{CI} 0.36-0.39 \%$ ). The risk of coronary death, myocardial infarction (MI) and coronary revascularization were reduced by $23 \%$ in patients with baseline $\mathrm{Lp}(\mathrm{a})>$ median $(37 \mathrm{nmol} / \mathrm{L}$ equal to $13 \mathrm{mg} / \mathrm{dL})$, while in individuals with baseline $\mathrm{Lp}(\mathrm{a})<$ median the risk reduction was only $7 \%$ (Table 2). When a threshold of $50 \mathrm{mg} / \mathrm{dL}$ was set, the NNT was 41 for the patients above the threshold and 71 for those below. The risk of MACE was the lowest for patients achieving both $\mathrm{Lp}(\mathrm{a})$ and LDL-C targets, i.e., $\leq 50$ and $70 \mathrm{mg} / \mathrm{dL}$, respectively, compared to patients who did not achieve those targets [84]. Interestingly, this evidence is similar to one observed in a pooled analysis from phase 3 ODYSSEY trials. Alirocumab was superior to placebo in reducing Lp(a) by $20-25 \%$, an effect leading to a $12 \%$ CV-relative risk-reduction. When patients were stratified according to $\mathrm{Lp}$ (a) levels, those grouped as $\geq 50 \mathrm{mg} / \mathrm{dL}$ had a relative risk reduction of $40 \%$, compared to $6 \%$ occurring in those ones achieving $\mathrm{Lp}(\mathrm{a})<50 \mathrm{mg} / \mathrm{dL}$ [85]. Finally, a further sub-analysis of the FOURIER trial reported that the higher the Lp(a) levels are, the greater the risk of a subsequent aortic stenosis or aortic valve replacement [86]. Overall, this observation complements that of Langsted et al., reporting that loss-of-function PCSK9 R46L carriers had lower levels of Lp(a) and a reduced risk of aortic valve stenosis compared to non-carriers [87]. FOURIER and ODYSSEY studies confirmed that Lp(a)-lowering can be an independent contributor to MACE reduction in ACS patients [82], a concept reinforced by the conclusions of the FOURIER study, in which higher levels of $\mathrm{Lp}(\mathrm{a})$ were associated with a raised risk of CVD events independent of LDL-C [84].

In patients with $\mathrm{Lp}(\mathrm{a})$ basal levels of $80 \mathrm{mg} / \mathrm{dL}$, evolocumab did not reduce arterial wall inflammation in the presence of modest falls in Lp(a) $(-14 \%)$. The arterial benefit of LDL-C reduction may be blunted in patients with persistently elevated $\mathrm{Lp}(\mathrm{a})$. This observation may open a new dawn in $\mathrm{CV}$ prevention since, so far, in FH patients, changes in arterial wall inflammation have been significantly correlated with LDL-C change, whereas no correlation has been demonstrated for Lp(a) [88]. 
Table 2. Impact of PCSK9 ${ }^{1}$ inhibitors on lipoprotein(a) levels.

\begin{tabular}{|c|c|c|}
\hline Drug & Study & Lp(a) ${ }^{2}$ Changes \\
\hline \multirow[t]{4}{*}{$\begin{array}{l}\text { PCSK9 } \\
\text { mAbs }^{4}\end{array}$} & $\begin{array}{l}\text { Pooled analysis from four phase II } \\
\text { studies with evolocumab [71] }\end{array}$ & $\begin{array}{l}\text { Baseline Lp(a) levels } \leq 125 \mathrm{nmol} / \mathrm{L} \\
-16.1 \%(70 \mathrm{mg} \text { Q2W })^{3} \\
-27.6 \%(105 \mathrm{mg} \mathrm{Q} 2 \mathrm{~W}) \\
-33.2 \%(140 \mathrm{mg} \mathrm{Q} 2 \mathrm{~W}) \\
-21.0 \%(280 \mathrm{mg} \mathrm{Q} 4 \mathrm{~W})^{3} \\
-25.3 \%(350 \mathrm{mg} \mathrm{Q} 4 \mathrm{~W}) \\
-28.7 \%(420 \mathrm{mg} \mathrm{Q} 4 \mathrm{~W}) \\
\text { Baseline Lp(a) levels }>125 \mathrm{nmol} / \mathrm{L} \\
-7.5 \%(70 \mathrm{mg} \mathrm{Q} 2 \mathrm{~W}) \\
-17.4 \%(105 \mathrm{mg} \mathrm{Q} 2 \mathrm{~W}) \\
-20.0 \%(140 \mathrm{mg} \mathrm{Q} 2 \mathrm{~W}) \\
-11.8 \%(280 \mathrm{mg} \mathrm{Q} 4 \mathrm{~W}) \\
-11.1 \%(350 \mathrm{mg} \mathrm{Q} 4 \mathrm{~W}) \\
-16.1 \%(420 \mathrm{mg} \mathrm{Q} 4 \mathrm{~W})\end{array}$ \\
\hline & Healthy patients (alirocumab) [73] & $-18.7 \%$ (from $-30.6 \%$ to $-11.2 \%$ ) \\
\hline & $\begin{array}{l}\text { ODISSEY OUTCOMES trial } \\
\text { (alirocumab) [82] }\end{array}$ & $\begin{array}{l}\text { Baseline Lp(a) levels }=21.2 \mathrm{mg} / \mathrm{dL} \text { (median) } \\
-5.0 \mathrm{mg} / \mathrm{dL} \text { (overall) } \\
-1.6 \mathrm{mg} / \mathrm{dL}(\mathrm{Q} 1,<6.7 \mathrm{mg} / \mathrm{dL})^{5} \\
-4.8 \mathrm{mg} / \mathrm{dL}(\mathrm{Q} 2,6.7 \text { to }<21.2 \mathrm{mg} / \mathrm{dL}) \\
-13.4 \mathrm{mg} / \mathrm{dL}(\mathrm{Q} 3,21.2 \text { to }<59.6 \mathrm{mg} / \mathrm{dL}) \\
-20.2 \mathrm{mg} / \mathrm{dL}(\mathrm{Q} 4,>59.6 \mathrm{mg} / \mathrm{dL})\end{array}$ \\
\hline & FOURIER trial (evolocumab) [84] & $\begin{array}{l}\text { Baseline Lp(a) } 37 \mathrm{nmol} / \mathrm{L} \text { (from } 13 \mathrm{nmol} / \mathrm{L} \text { to } 165 \\
\text { nmol/L; median) } \\
-26.9 \% \text { (from }-6.2 \% \text { to }-46.7 \% \text { ) }\end{array}$ \\
\hline \multirow{3}{*}{ PCSK9 antisense } & ORION-1 (inclisiran) [89] & $\begin{array}{l}\text { from }-14 \% \text { to }-18 \% \text { (single dose group) } \\
\text { from }-15 \% \text { to }-26 \% \text { (double dose group) }\end{array}$ \\
\hline & ORION-9 (inclisiran) & Lp(a): $-17.2 \%$ vs. baseline \\
\hline & $\begin{array}{l}\text { ORION-10 and ORION } 11 \\
\text { (inclisiran) [90] }\end{array}$ & $\begin{array}{l}\text { ORION } 10 \\
\text { Lp(a): }-25.6 \% \text { (placebo adjusted) } \\
\text { ORION } 11 \\
\text { Lp(a): }-18.6 \% \text { (placebo adjusted) }\end{array}$ \\
\hline
\end{tabular}

${ }^{1}$ PCSK9, proprotein convertase subtilisin/kexin type $9 ;{ }^{2} \mathrm{Lp}(\mathrm{a})$, lipoprotein $(\mathrm{a}) ;{ }^{3} \mathrm{QW}$, once weekly; Q2W, every two weeks; QW4, every 4 weeks; ${ }^{4} \mathrm{mAb}$, monoclonal antibodies; ${ }^{5} \mathrm{Q}$, quartile.

A new antagonist of PCSK9 with a different mode of action, inclisiran, acting as a silencer RNA (siRNA) for the PCSK9 gene, has also been evaluated in terms of Lp(a) reduction. Patients were given single (200, 300 and $500 \mathrm{mg}$ ) or two dose starting regimens (100, 200 or $300 \mathrm{mg}$ on days 1 and 90). In addition to the reduction of LDL-C and apo B levels, $80 \%$ of the participants showed a reduction of $\mathrm{Lp}$ (a) levels at the end of the trial. However, due to the very large variability of $\mathrm{Lp}$ (a) concentrations, none of the differences were significant [89] (Table 2). Recently, in ASCVD patients (ORION-10 trial) or in patients with an equivalent ASCVD risk (ORION-11 trial), inclisiran (300 mg) was superior to the placebo in reducing $\mathrm{Lp}(\mathrm{a})$ levels by $25.6 \%$ and $18.6 \%$, respectively (both placebo adjusted) [90]. In adult $\mathrm{HeFH}$ patients with LDL-C of $153 \mathrm{mg} / \mathrm{dL}$ ( $3.95 \mathrm{mmol} / \mathrm{L})$, administration of inclisiran $(300 \mathrm{mg})$ lowered LDL-C by $47.9 \%$ (vs. placebo), and Lp(a) by $17.2 \%$ (vs. baseline) [91].

\section{Other Approaches to Lower Lp(a) Levels}

Fibrates. An impressive reduction of Lp(a) after bezafibrate was reported [92], i.e., up to $39 \%$ in patients with $\mathrm{Lp}(\mathrm{a})>30 \mathrm{mg} / \mathrm{dL}$. A somewhat lower reduction $(-13 \%)$ was earlier reported by Maggi et al. [93], and a similarly modest activity was described for gemfibrozil [94]. These and other studies have led to the conclusion that fibrates are not the drugs of choice for managing Lp(a) 
elevations [95], although a meta-analysis comparing fibrates and statins indicated that the former ones do not lead to Lp(a) rises, as occurs with statins [96].

Vitamin C. A fascinating correlation between elevated $\mathrm{Lp}(\mathrm{a})$, low vitamin $\mathrm{C}$ and atherosclerosis was earlier described by Rath and Pauling [97]. These authors reported the accumulation of Lp(a) in atherosclerotic lesions of the hypoascorbemic guinea pig, and hypothesized that $\mathrm{Lp}(\mathrm{a})$ may be a surrogate for ascorbate in species unable to synthesize it. The presence of $L p(a)$ could provide properties shared with ascorbate, such as improved wound-healing and prevention of lipid peroxidation [31]. This hypothesis was not confirmed by other authors, and did not find support in the clinic, where ascorbic acid supplementation (1 g/day) did not significantly affect Lp(a) concentrations [98].

Sex hormone therapies. Post-menopausal norethisterone treatment led to a $47 \%$ reduction of $\mathrm{Lp}(\mathrm{a})$ levels [99], whereas the effect was found to be less marked in post-menopausal women given low doses of estradiol valerate ( $2 \mathrm{mg} /$ day) [100]. Larger effects $(-17 \%$ to $-23 \%)$ were instead reported in post-menopausal women on conjugated estrogens with or without medroxyprogesterone acetate [101]. However, hormone replacement therapy cannot be recommended for the sole purpose of lowering $\mathrm{Lp}(\mathrm{a})$ [102]. A reduction of $40 \%$ in $\mathrm{Lp}$ (a) levels was shown after tamoxifen administration in patients diagnosed with breast cancer [103]. Finally, dramatic $L p(a)$ reductions have been reported in body builders on stanazolol [-65\% Lp(a)] [104] or danazol (-78\%) [105].

\section{Lipoprotein Apheresis (LA) to Reduce Lipoprotein(a)}

Although LA, within the therapeutic regimen of lipid disorders, is often considered as a therapy of last resort, guidelines differ in defining which patients to treat, and under which circumstances [106]. Some of these guidelines recommend apheresis as a first-line treatment in patients with $\mathrm{HoFH}$, and after drug therapy failure in patients with heterozygous $(\mathrm{He}) \mathrm{FH}$, with differences also in LA treatment frequency (weekly or biweekly) $[107,108]$. LA is highly effective in reducing Lp(a) levels, i.e., approximately $57 \mathrm{mg} / \mathrm{dL}$ or $39 \%$ when comparing Lp(a) levels measured before the start of apheresis and the interval mean values during the apheretic procedure [24]. Currently, LA is mainly used in two different clinical settings, i.e., significantly elevated LDL-C or Lp(a). In patients with hyperlipoproteinemia(a), and on maximally tolerated lipid-lowering medications, LA seems to lower the progression of atherosclerosis, leading to a reduced number of CV events [109-111]. In the case of CV events, when comparing the time intervals from the start of LA to a similar time on no LA, LA may lead to a more than $80 \%$ risk-reduction [112-114]. Evidence from case studies showed that apheresis is more effective in patients with elevated Lp(a) levels when compared with those with normal concentrations [115]. Data from the Low-Density Lipoprotein Apheresis Coronary Atherosclerosis Prospective Study (L-CAPS) trial showed that intensive cholesterol lowering by apheresis prevented coronary atherosclerosis progression. The restenosis rate was $12.5 \%$ in the $\mathrm{FH}$ patients whose $\mathrm{Lp}(\mathrm{a})$ levels dropped more than 50\%, compared to 53\% in those with lesser Lp(a) reductions [116].

The European Atherosclerosis Society Consensus Panel recommended that Lp(a) levels should be reduced below $50 \mathrm{mg} / \mathrm{dL}$ in extreme cases by LA [26]. The HEART UK Guidelines recommended LA for patients on maximally tolerated lipid-lowering therapies and with progressive coronary heart disease and persistent elevations of $\mathrm{Lp}(\mathrm{a})>60 \mathrm{mg} / \mathrm{dL}$ and LDL-C $>125 \mathrm{mg} / \mathrm{dL}$ (3.23 mmol/L) [117]. In Germany, Lp(a) levels exceeding $60 \mathrm{mg} / \mathrm{dL}$, along with progressive CVD, were approved as an indication for regular LA in 2008 by the Joint Federal Committee. The American Society for Apheresis recommends the use of LA for the treatment of elevated $\mathrm{Lp}(\mathrm{a})(>50 \mathrm{mg} / \mathrm{dL})$ in CVD patients [118]. In the US, the Food and Drug Administration approved LA for HoFH patients with LDL-C $>500 \mathrm{mg} / \mathrm{dL}$ (12.92 mmol/L) (beginning in childhood), for HeFH with LDL-C $>300 \mathrm{mg} / \mathrm{dL}(7.75 \mathrm{mmol} / \mathrm{L})$ and no sign of CVD, or with known CVD and LDL-C > $200 \mathrm{mg} / \mathrm{dL}$ (5.17 mmol/L) [119]. In Japan, LA is approved for patients with CVD and total cholesterolemia $>250 \mathrm{mg} / \mathrm{dL}(6.46 \mathrm{mmol} / \mathrm{L})$ [120]. As elsewhere reviewed in detail [121], available LA techniques are categorized as selective (immune adsorption, dextran sulfate adsorption, heparin precipitation, cascade filtration and polyacrylamide adsorption) or non-selective (plasma exchange; Table 3). 
Table 3. Impact of different lipoprotein apheretic approaches on LDL-C and Lp(a) levels.

\begin{tabular}{|c|c|c|}
\hline Lipoprotein Apheresis & Description & Reduction \\
\hline \multirow{4}{*}{ Adsorption } & $\begin{array}{l}\text { DALI (direct adsorption of lipoproteins). Electrostatic } \\
\text { interaction of negatively charged polyacrylate anions with } \\
\text { positively charged apoB }\end{array}$ & $\begin{array}{l}\text { LDL-C }^{1}: \\
53-76 \% \\
\text { Lp(a) }{ }^{2}: 28-74 \%\end{array}$ \\
\hline & $\begin{array}{l}\text { DSA (Dextran sulfate-cellulose-based-adsorption). } \\
\text { Electrostatic interaction of negatively dextransulfate with } \\
\text { positively charged apoB }\end{array}$ & $\begin{array}{l}\text { LDL-C: } 49-75 \% \\
\operatorname{Lp}(\mathrm{a}): 19-70 \%\end{array}$ \\
\hline & $\begin{array}{l}\text { IMA (immunoadsorption). Plasma is passed through } \\
\text { columns containing polyclonal anti-apoB100 antibodies }\end{array}$ & $\begin{array}{l}\text { LDL-C: } 62-69 \% \\
\text { Lp(a): } 51-71 \%\end{array}$ \\
\hline & $\begin{array}{l}\text { Lipopac ( } L p(a) \text { specific). Plasma is passed through columns } \\
\text { containing polyclonal anti-apo(a) antibodies }\end{array}$ & $\begin{array}{l}\text { LDL-C: } 7 \% \\
\text { Lp(a): } 59-88 \%\end{array}$ \\
\hline \multirow[t]{2}{*}{ Filtration } & $\begin{array}{l}\text { MONET (Membrane Filtration Optimized Novel } \\
\text { Extracorporeal Treatment). Series of filters eliminate LDL } \\
\text { and Lp(a) from plasma based on size properties }\end{array}$ & $\begin{array}{l}\text { LDL-C: } 52-62 \% \\
\text { Lp(a): } 53-59 \%\end{array}$ \\
\hline & $\begin{array}{l}\text { Lipid filtration. Series of filters eliminate LDL and Lp(a) } \\
\text { from plasma based on size properties }\end{array}$ & $\begin{array}{l}\text { LDL-C: } 61 \% \\
\operatorname{Lp}(\mathrm{a}): 61 \%\end{array}$ \\
\hline Precipitation & $\begin{array}{l}\text { HELP (Heparin-induced extracorporeal LDL precipitation). } \\
\text { Precipitation of a complex consisting of heparin, LDL, } \\
\mathrm{Lp}(\mathrm{a}) \text {, and fibrinogen at } \mathrm{pH}=5.2\end{array}$ & $\begin{array}{l}\text { LDL-C: } 55-61 \% \\
\text { Lp(a): } 55-68 \%\end{array}$ \\
\hline Plasma Exchange & \multicolumn{2}{|c|}{$\begin{array}{l}\text { Although plasma exchange is still used in some centers, it is increasingly } \\
\text { being replaced by selective LA, except when treating patients with severe } \\
\text { hypertriglyceridemia [122] }\end{array}$} \\
\hline
\end{tabular}

Variability among procedures relates partially to differences in the volume of plasma and blood treated. ${ }^{1}$ LDL-C, low-density lipoprotein-cholesterol; ${ }^{2} \mathrm{Lp}(\mathrm{a})$, lipoprotein(a).

Briefly, the most commonly used LA systems share the specific adsorption of apoB, constitutive of VLDL, LDL and Lp(a). ApoB-containing lipoproteins are removed either by precipitation in the excess of heparin (HELP Braun) at acidic $\mathrm{pH}$ (5.2), or by the binding of positively charged apoB to the negatively charged surface dextran sulfate coupled to cellulose beads (DSA), or by apoB-immunoabsorption [123]. While removal efficiency differs among the systems [124], in FH patients all techniques rapidly remove LDL-C (55-70\%) as well as Lp(a) mass (50-60\%) [125]. Later publications by the same group indicated a higher removal rate [24]. However, the percentage changes reported in Table 3 reflect not only the intrinsic efficiency of each method in removing plasma lipoproteins, but also differences in the volume of blood or plasma treated and the extent of haemodilution caused by the anticoagulant used [126]. Typically, from 4- to 6-L exchanges of plasma are carried out for 2-4 h weekly or biweekly [127].

An inherent drawback of LA is the cyclical rebound of LDL-C within 1 to 2 weeks between apheretic procedures. $\mathrm{Lp}(\mathrm{a})$ rebounds at a slower rate than LDL-C, but with a similar monoexponential function [106]. Thus, despite an acute decrement of 70-75\%, regular apheresis can translate into a significant interval mean $\mathrm{Lp}(\mathrm{a})$ reduction between $25 \%$ and $40 \%$ [128]. Specifically, depending on the $\mathrm{Lp}(\mathrm{a})$ baseline and the selected interval, a biweekly apheresis generally results in a much lower interval mean reduction $(20 \%)$, compared to a weekly procedure $(36 \%)[109,129]$. This bulk of reduction also persisted in patients undergoing long-term LA, wherein mean pre-apheresis levels of Lp(a) were reduced by $22 \%$ after 1 year, and by $19 \%$ after three years $[130,131]$. To reduce the lipoprotein rebound, one strategy is the use of lipid-lowering therapies in between the procedures. The effect of PCSK9 inhibition on the frequency of standard LA treatments was the focus of the ODYSSEY ESCAPE study [132]. Although LA was discontinued in $63.4 \%$ of patients on alirocumab and the rate was reduced at least $50 \%$ in $92.7 \%$ of patients, any additive effect of alirocumab on top of LA on Lp(a) levels was not found [133]. Santos et al. [134], in HoFH and severe HeFH patients, showed that long-term administration of evolocumab (over a median of 4.1 years) allowed 3 out of $34 \mathrm{HoFH}$, and 13 out of 27 severe HeFH, patients to discontinue LA. The DE LAVAL study showed that among patients on 
weekly or every-two-week LA and with a moderate- to high-intensity statin background, evolocumab led $>50 \%$ of patients to reach LDL-C $<68 \mathrm{mg} / \mathrm{dL}(1.76 \mathrm{mmol} / \mathrm{L})$, demonstrating that evolocumab may, in these cases, replace LA [135]. Finally, the EVOLAFER01 trial enrolling HeFH patients on long-term LA therapy reported evolocumab to be superior to LA in reducing LDL-C and Lp(a), and that the combination of evolocumab plus LA could represent a therapeutic alternative to lowering LDL-C and Lp(a) levels in patients with very high CV risk [136]. However, these studies did not specifically address the lowering of $\mathrm{Lp}(\mathrm{a})$. Relative to real-life studies on long-term apheresis patients, the use of PCSK9 inhibitors seems unable to replace LA in $75 \%$ of patients, and in $45 \%$ of people with isolated hypercholesterolemia, thus pointing out the role of LA as a last resort lipid-lowering option [137].

From a clinical point of view, LA can also modify a number of pathological processes associated with CVD: it improves markers of vascular inflammation, and decreases fibrinogen, E-selectin, vascular cellular adhesion molecule-1, intercellular adhesion molecule-1, monocyte chemoattractant protein-1, lipopolysaccharide binding protein, matrix metalloproteinase and tissue inhibitor of metalloproteinase [138-141]. Among these effects, the most important one is the restoration of an effective myocardial blood flow induced by LA, well established many years ago [142] and recently confirmed [143], in clinical cases of refractory angina associated with raised Lp(a). Improvement of myocardial blood flow can be assessed, among other means, by Positron Emission Tomography (PET) and by echo-doppler sonography [144]. These hemodynamic effects are not far from those exerted by percutaneous transluminal coronary angioplasty (PTCA). This additional value attributable to $\mathrm{Lp}(\mathrm{a})$ apheresis in this condition makes this technique more impactful in cardiological practice. Furthermore, cardiac magnetic resonance imaging allows one to detect treatment-related changes in regional myocardial perfusion in patients with elevated $\mathrm{Lp}(\mathrm{a})(\geq 117 \mathrm{mg} / \mathrm{dL})$ and coronary artery disease undergoing LA [145]. The possible application of selective Lp(a) apheresis also appears to offer a promising approach to the prevention of $\mathrm{Lp}(\mathrm{a})$ associated to $\mathrm{CV}$ risk. The specific immunosorbent column named 'Lp(a) Lipopak' (POCARD, Moscow, Russia) represents, so far, the most efficient LA able to selectively reduce $\mathrm{Lp}$ (a) levels by $88 \%$, compared to pretreatment [146] (Table 3). In patients with ischemic heart disease, an 18-month application of $\mathrm{Lp}(\mathrm{a})$ apheresis reduced the diameter of stenosis $(-5.05 \%)$ and total atheroma volume $\left(-4.60 \mathrm{~mm}^{3}\right)$, and raised minimal coronary lumen diameter (+14\%) [147]. Another crucial aspect worth mentioning is the ability of Lp(a) to bind and transport oxidized phospholipids (OxPLs) that represent a key component of the atherothrombotic risk associated with $\mathrm{Lp}(\mathrm{a})$ [148]. OxPLs are sequestered on $\mathrm{Lp}(\mathrm{a})$ and subjected to degradation by the Lp(a)-associated lipoprotein-associated phospholipase A2 (Lp-PLA2), suggesting that Lp(a) might be a scavenger of OxPL [149]. Upon LA, there is an acute reduction of Lp-PLA(2) (roughly -20\%), an effect independent of LDL-C when LA becomes a chronic treatment. This could explain the potential mechanism by which LA reduces coronary heart disease risk [140].

\section{Antisense Antinuocleotide}

In view of the apparent increase of $\mathrm{Lp}(\mathrm{a})$ synthesis in carriers of elevated $\mathrm{Lp}(\mathrm{a})$, and consequent reductions by PCSK9 antagonists, the potential of biosynthetic drug treatments appears to be best targeted to synthesis. In particular, the use of appropriate antisense oligonucleotides (ASOs) appears to be most suitable [150]. The first developed APO-(a)Rx by IONIS was a second generation 2-O-(2-metoxyethyl) (2-MOE)-modified ASO with improved potency, duration and tolerability. Designed to reduce the synthesis of apo(a) in the liver, this ASO was tested in a double-blind phase I study, at doses between 50 and $400 \mathrm{mg} /$ day. Single doses did not lead to any reduction of Lp(a) at day 30, but six doses of 100-300 $\mathrm{mg}$ resulted in a dose-dependent percentage reduction of Lp(a) concentrations of $39.6 \%$ from baseline in the $100 \mathrm{mg}$ group, up to $77.8 \%$ in the $300 \mathrm{mg}$ group [151].

To assess the potential validity of this approach, also the frequently concomitant presence of stenotic aortic valves, a follow up study evaluated 64 participants with elevated Lp(a) concentrations (52-182 mg/dL) [151]. This time the variant IONIS-APO(a)Lrx was tested, i.e., a ligand-conjugated ASO with a triantennary $\mathrm{N}$-acetylgaloctosamine (GalNAc) covalently attached, to allow rapid and 
specific uptake by hepatocytes. In a proof-of-concept phase 1/2a trial in healthy volunteers with Lp(a) levels $\geq 30 \mathrm{mg} / \mathrm{dL}$, this ASO led to a stepwise reduction in fasting Lp(a) levels, the maximal benefit occurring at day $30:-24.8 \%(10 \mathrm{mg}),-35.1 \%(20 \mathrm{mg}),-48.2 \%(40 \mathrm{mg}),-82.5 \%(80 \mathrm{mg})$ and $-84.5 \%$ (120 mg) [151] (Table 4).

Table 4. Impact of antisense oligonucleotide APO(a) on lipoprotein(a) levels.

\begin{tabular}{|c|c|c|}
\hline Drug & Study & Lp(a) ${ }^{1}$ Changes \\
\hline \multirow{3}{*}{ Antisense antinucleotide } & APO(a)Rx [151] & $\begin{array}{l}\mathrm{Lp} \text { (a) } 125-437 \mathrm{nmol} / \mathrm{L}:-66.8 \% \\
\mathrm{Lp} \text { (a) concentration } \geq 438 \mathrm{nmol} / \mathrm{L}:-71.6\end{array}$ \\
\hline & $\mathrm{APO}(\mathrm{a}) \mathrm{L}_{\mathrm{Rx}}[151]$ & $\begin{array}{l}\text { Single-ascending-dose group: } \\
-24.8 \%(95 \% \mathrm{CI} 3.1-67.1) \text { at day } 30 \text { (10 mg group) } \\
-35.1 \%(2.2-78.8) \text { at day } 30 \text { (20 mg group) } \\
-48.2 \%(10.9-78.4) \text { at day } 30 \text { (40 mg group) } \\
-82.5 \%(50.5-109.2) \text { at day } 30 \text { (80 mg group) } \\
-84.5 \%(65.2-112.6) \text { at day } 30 \text { (120 mg group) } \\
\text { Multiple-ascending dose group: } \\
-59.4 \%(95 \% \text { CI } 33.5-79.1) \text { at day } 36 \text { (10 mg group) } \\
-72.3 \%(51.6-87.7) \text { at day } 36 \text { (20 mg group) } \\
-82.4 \%(67.6-99.8) \text { at day } 36 \text { (40 mg group) }\end{array}$ \\
\hline & $\mathrm{APO}(\mathrm{a}) \mathrm{L}_{\mathrm{Rx}}[152]$ & $\begin{array}{l}L p(a)>60 \mathrm{mg} / \mathrm{dl}(150 \mathrm{nmol} / \mathrm{L}) \\
-35 \%\left(20 \mathrm{mg} \text { of AKCEA-APO(a) } \mathrm{L}_{\mathrm{Rx}} \mathrm{Q} 4 \mathrm{~W}\right) \\
-56 \%\left(40 \mathrm{mg} \text { of AKCEA-APO(a) } \mathrm{L}_{\mathrm{Rx}} \mathrm{Q} 4 \mathrm{~W}\right) \\
-58 \%\left(20 \mathrm{mg} \text { of AKCEA-APO(a) } \mathrm{L}_{\mathrm{Rx}} \mathrm{Q} 2 \mathrm{~W}\right) \\
-72 \%\left(60 \mathrm{mg} \text { of AKCEA-APO(a) } \mathrm{L}_{\mathrm{Rx}} \mathrm{Q} 4 \mathrm{~W}\right) \\
-80 \%\left(20 \mathrm{mg} \text { of AKCEA-APO(a) } \mathrm{L}_{\mathrm{rx}} \mathrm{QW}\right)\end{array}$ \\
\hline
\end{tabular}

\footnotetext{
${ }^{1}$ Lp(a), lipoprotein(a).
}

The most recent multicenter international dose-ranging phase $2 \mathrm{~b}$ trial was carried out on 286 patients with pre-existing CVD and baseline Lp(a) $>60 \mathrm{mg} / \mathrm{dl}$. Doses were 20, 40, $60 \mathrm{mg}$ or placebo every 4 weeks (Q4W), $20 \mathrm{mg}$ every 2 weeks (Q2W) or $20 \mathrm{mg}$ once weekly (QW). Duration was 25-27 weeks. IONIS-APO(a) Lrx resulted in a dose-dependent reduction of $\mathrm{Lp}(\mathrm{a})$ in all treated groups. Mean percentage decreases were of $35 \%$ at $20 \mathrm{mg} \mathrm{Q} 4 \mathrm{~W}, 56 \%$ at $40 \mathrm{mg} \mathrm{Q} 4 \mathrm{~W}, 58 \%$ at $20 \mathrm{mg}$ Q2W, $72 \%$ at $60 \mathrm{mg}$ Q4W and $80 \%$ at $20 \mathrm{mg}$ QW. Placebo (saline) only reduced Lp(a) by $6 \%$. The product was well tolerated, with no changes in platelet number or liver and renal function, and no influenza-like symptoms. Injection site reactions occurred in approximately $7 \%$ of cases, the most common associated adverse reactions being erythema ( $26 \%)$; only one patient discontinued treatment because of an injection site reaction. There were no potential pro-inflammatory effects as assessed from the determination of high-sensitivity CRP levels, which were maintained between 2 and $3 \mathrm{mg} / \mathrm{L}$ across groups with no statistically significant differences [152] (Table 4).

Further, looking at the benefit driven by a dramatic Lp(a) lowering, in CVD patients with elevated Lp(a), IONIS-APO(a) Lrx led to a reduction of multiple immune response-related pathways, including interferon (IFN) $\alpha$, IFN $\gamma$ and Toll-like receptor (TLR) pathways. Expression of C-C chemokine receptor type 2 (CCR2), CX3C chemokine receptor 1 (CX3CR1) and TLR2 were also reduced. Trans-endothelial migration activity of monocytes was reduced $(-22 \%)$. Conversely, a modest $\mathrm{Lp}(\mathrm{a})$ lowering driven by PCSK9 inhibition (evolocumab) did not result in such effects, despite a 65\% reduction in LDL-C [153].

\section{Future Perspectives and Conclusions}

In a scenario missing a pharmacological approach to lowering $L p(a)$ to the extent required to achieve a CV benefit, in patients with progressive ASCVD and high plasma Lp(a), a potentially valuable therapeutic option is LA, alone or in combination with PCSK9 inhibitors. However, because of the difficult standardization of apheretic modalities, there is still an unclear response to the main question of whether the $\mathrm{Lp}(\mathrm{a})$ reduction will have beneficial effects on the CV system, even in the 
clinical setting of isolated elevated Lp(a) levels. The prospective study by Roeseler et al. [4] confirmed a significant $\mathrm{CV}$ benefit over 5 years of follow-up with different apheretic techniques in patients with hyperlipoproteinemia(a), with a significant reduction of $\mathrm{CV}$ events over the prior non-apheretic treatment. However, it should be taken into consideration that these studies all suffer from potential confounding, such as the lack of any scope for ruling out the effect of LA on other drivers of events, such as LDL or fibrinogen. Moreover, to determine the contribution of $\mathrm{Lp}(\mathrm{a})$ apheresis, a study with a controlled prospective randomized design, enrolling only patients with elevated $L p(a)$, should be planned [128].

While the use of PCSK9 inhibitors has led to a mean fairly modest reduction in Lp(a) levels $(20-25 \%)$, there is no currently accepted indication for the use of these biosynthetic compounds to treat hyperlipoproteinemia(a) [154]. However, in combination with LA, the use of PCSK9 inhibitors decreases the need for apheresis, as most patients with HeHF and other forms of hypercholesterolemia respond very well to this therapy. Instead, contrasting conclusions have been reached in the case of statins, while ezetimibe monotherapy provided a modest $7 \%$ reduction [155]. Relative to mipomersen, although the potential benefit in reducing $\mathrm{Lp}$ (a) was between $20 \%$ and $50 \%$ [156], the manufacturing of the compound was discontinued (2018) and the product is not clinically available [150]. Interestingly, although not approved for clinical use [157], inhibitors of cholesteryl ester transfer protein lowered $\mathrm{Lp}(\mathrm{a})$ in a range between $25 \%$ and $40 \%$ [156]. Finally, in the era of RNA-based therapies, a new dawn is represented by $\mathrm{APO}(\mathrm{a}) \mathrm{L}_{\mathrm{rx}}$ [152]. The $\mathrm{Lp}(\mathrm{a})$ Horizon trial will test the effect of the ASO TQJ230 against apo(a) in patients with previous MI, stroke or symptomatic peripheral artery disease, with an optimized LDL-C lowering therapy and Lp(a) $\geq 70 \mathrm{mg} / \mathrm{dL}$. The estimated completion date is March 2024 (NCT04023552). However, future safety and cost-effectiveness studies are required to establish the role of these new agents in clinical practice.

Finally, moving to a biochemical point of view, adjusting LDL-C concentration for Lp(a)-C improves the diagnostic accuracy of the Dutch Lipid Clinic Network and Simon Broome criteria, especially for patients with $\mathrm{Lp}(\mathrm{a})>100 \mathrm{mg} / \mathrm{dL}$ and LDL-C $<251 \mathrm{mg} / \mathrm{dL}$ (6.49 mmol/L) [36]. It should be taken into consideration that each $\mathrm{Lp}$ (a) particle is composed of about $30-45 \%$ of cholesterol, i.e., $\mathrm{Lp}(\mathrm{a})-\mathrm{C}$ is equal to $\mathrm{Lp}(\mathrm{a})$ total mass in $\mathrm{mg} / \mathrm{dL} / 3$. Thus, when $\mathrm{Lp}(\mathrm{a})$ total mass is high, the $\mathrm{Lp}(\mathrm{a})-\mathrm{C}$ contribution to the LDL-C is significant [158]. Considering that $L p(a)$-corrected $L D L-C(m g / d L)=L D L-C$ $(\mathrm{mg} / \mathrm{dL})$ - $[\mathrm{Lp}(\mathrm{a})(\mathrm{mg} / \mathrm{dL}) \times 0.30], \mathrm{Lp}(\mathrm{a})$-corrected LDL-C is $55-70 \mathrm{mg} / \mathrm{dL}$ in a person with an LDL-C concentration of $100 \mathrm{mg} / \mathrm{dL}$ and an Lp(a) concentration of $100 \mathrm{mg} / \mathrm{dL}[159,160]$. If LDL-C is expressed in $\mathrm{mmol} / \mathrm{L}$ the formula is as follows: $L p(a)$-corrected $L D L-C(m m o l / L)=L D L-C(m m o l / L)-[L p(a)(m g / d L) \times$ 0.0078] [161]. Although the confounding effect of $\mathrm{Lp}(\mathrm{a})$ cholesterol on the phenotypic diagnosis of $\mathrm{FH}$ in people with hyperlipoproteinemia(a) has been highlighted, to confirm its practical implications for the care of patients requires further studies [74].

Author Contributions: Conceptualization, M.F.G., A.C., and M.R.; writing—original draft preparation, M.F.G., M.R., C.R.S.; writing - review and editing, M.E., T.S.; funding acquisition, C.R.S. All authors have read and agreed to the published version of the manuscript.

Funding: This research was funded by Cariplo Foundation grant numbers 2015-0552 and 2018-0511 and grants from MIUR Progetto Eccellenza. The APC was funded by Fondazione Carlo Sirtori.

Conflicts of Interest: MFG, CRS, ME, TS declare no conflict of interest. AC received honoraria from AstraZeneca, AMGEN, Sanofi, Recordati, Novartis, MSD, Mediolanum, DOC, Mylan and Pfizer.

\section{References}

1. Emerging Risk Factors Collaboration; Erqou, S.; Kaptoge, S.; Perry, P.L.; Di Angelantonio, E.; Thompson, A.; White, I.R.; Marcovina, S.M.; Collins, R.; Thompson, S.G.; et al. Lipoprotein(a) concentration and the risk of coronary heart disease, stroke, and nonvascular mortality. JAMA 2009, 302, 412-423. [CrossRef] [PubMed]

2. Kamstrup, P.R.; Tybjaerg-Hansen, A.; Steffensen, R.; Nordestgaard, B.G. Genetically elevated lipoprotein(a) and increased risk of myocardial infarction. JAMA 2009, 301, 2331-2339. [CrossRef] [PubMed] 
3. Saleheen, D.; Haycock, P.C.; Zhao, W.; Rasheed, A.; Taleb, A.; Imran, A.; Abbas, S.; Majeed, F.; Akhtar, S.; Qamar, N.; et al. Apolipoprotein(a) isoform size, lipoprotein(a) concentration, and coronary artery disease: A mendelian randomisation analysis. Lancet Diabetes Endocrinol. 2017, 5, 524-533. [CrossRef]

4. Roeseler, E.; Julius, U.; Heigl, F.; Spitthoever, R.; Heutling, D.; Breitenberger, P.; Leebmann, J.; Lehmacher, W.; Kamstrup, P.R.; Nordestgaard, B.G.; et al. Lipoprotein Apheresis for Lipoprotein(a)-Associated Cardiovascular Disease: Prospective 5 Years of Follow-Up and Apolipoprotein(a) Characterization. Arterioscler. Thromb. Vasc. Biol. 2016, 36, 2019-2027. [CrossRef]

5. Frank, S.; Krasznai, K.; Durovic, S.; Lobentanz, E.M.; Dieplinger, H.; Wagner, E.; Zatloukal, K.; Cotten, M.; Utermann, G.; Kostner, G.M.; et al. High-level expression of various apolipoprotein(a) isoforms by "transferrinfection": The role of kringle IV sequences in the extracellular association with low-density lipoprotein. Biochemistry 1994, 33, 12329-12339. [CrossRef]

6. Trieu, V.N.; McConathy, W.J. A two-step model for lipoprotein(a) formation. J. Biol. Chem. 1995, 270, 15471-15474. [CrossRef]

7. Von Zychlinski, A.; Williams, M.; McCormick, S.; Kleffmann, T. Absolute quantification of apolipoproteins and associated proteins on human plasma lipoproteins. J. Proteomics 2014, 106, 181-190. [CrossRef]

8. Vuorio, A.; Watts, G.F.; Schneider, W.J.; Tsimikas, S.; Kovanen, P.T. Familial hypercholesterolemia and elevated lipoprotein(a): Double heritable risk and new therapeutic opportunities. J. Intern. Med. 2020, 287, 2-18. [CrossRef]

9. Alonso, R.; Andres, E.; Mata, N.; Fuentes-Jimenez, F.; Badimon, L.; Lopez-Miranda, J.; Padro, T.; Muniz, O.; Diaz-Diaz, J.L.; Mauri, M.; et al. Lipoprotein(a) levels in familial hypercholesterolemia: An important predictor of cardiovascular disease independent of the type of LDL receptor mutation. J. Am. Coll. Cardiol. 2014, 63, 1982-1989. [CrossRef]

10. Berberich, A.J.; Hegele, R.A. The complex molecular genetics of familial hypercholesterolaemia. Nat. Rev. Cardiol. 2019, 16, 9-20. [CrossRef]

11. Langsted, A.; Kamstrup, P.R.; Benn, M.; Tybjaerg-Hansen, A.; Nordestgaard, B.G. High lipoprotein(a) as a possible cause of clinical familial hypercholesterolaemia: A prospective cohort study. Lancet Diabetes Endocrinol. 2016, 4, 577-587. [CrossRef]

12. Kraft, H.G.; Lingenhel, A.; Raal, F.J.; Hohenegger, M.; Utermann, G. Lipoprotein(a) in homozygous familial hypercholesterolemia. Arterioscler. Thromb. Vasc. Biol. 2000, 20, 522-528. [CrossRef]

13. Trinder, M.; DeCastro, M.L.; Azizi, H.; Cermakova, L.; Jackson, L.M.; Frohlich, J.; Mancini, G.B.J.; Francis, G.A.; Brunham, L.R. Ascertainment Bias in the Association Between Elevated Lipoprotein(a) and Familial Hypercholesterolemia. J. Am. Coll. Cardiol. 2020, 75, 2682-2693. [CrossRef] [PubMed]

14. Lackner, C.; Cohen, J.C.; Hobbs, H.H. Molecular definition of the extreme size polymorphism in apolipoprotein(a). Hum. Mol. Genet. 1993, 2, 933-940. [CrossRef] [PubMed]

15. Schmidt, K.; Noureen, A.; Kronenberg, F.; Utermann, G. Structure, function, and genetics of lipoprotein (a). J. Lipid Res. 2016, 57, 1339-1359. [CrossRef]

16. Gencer, B.; Kronenberg, F.; Stroes, E.S.; Mach, F. Lipoprotein(a): The revenant. Eur. Heart J. 2017, 38, 1553-1560. [CrossRef]

17. Wilson, D.P.; Jacobson, T.A.; Jones, P.H.; Koschinsky, M.L.; McNeal, C.J.; Nordestgaard, B.G.; Orringer, C.E. Use of Lipoprotein(a) in clinical practice: A biomarker whose time has come. A scientific statement from the National Lipid Association. J. Clin. Lipidol. 2019, 13, 374-392. [CrossRef]

18. Scharnagl, H.; Stojakovic, T.; Dieplinger, B.; Dieplinger, H.; Erhart, G.; Kostner, G.M.; Herrmann, M.; Marz, W.; Grammer, T.B. Comparison of lipoprotein (a) serum concentrations measured by six commercially available immunoassays. Atherosclerosis 2019, 289, 206-213. [CrossRef]

19. Roth, C.; Krychtiuk, K.A.; Gangl, C.; Schrutka, L.; Distelmaier, K.; Wojta, J.; Hengstenberg, C.; Berger, R.; Speidl, W.S. Lipoprotein(a) plasma levels are not associated with survival after acute coronary syndromes: An observational cohort study. PLoS ONE 2020, 15, e0227054. [CrossRef]

20. Tsimikas, S.; Stroes, E.S.G. The dedicated "Lp(a) clinic": A concept whose time has arrived? Atherosclerosis 2020, 300, 1-9. [CrossRef]

21. Burgess, S.; Ference, B.A.; Staley, J.R.; Freitag, D.F.; Mason, A.M.; Nielsen, S.F.; Willeit, P.; Young, R.; Surendran, P.; Karthikeyan, S.; et al. Association of LPA Variants With Risk of Coronary Disease and the Implications for Lipoprotein(a)-Lowering Therapies: A Mendelian Randomization Analysis. JAMA Cardiol. 2018, 3, 619-627. [CrossRef] 
22. Lamina, C.; Kronenberg, F.; Lp, G.C. Estimation of the Required Lipoprotein(a)-Lowering Therapeutic Effect Size for Reduction in Coronary Heart Disease Outcomes: A Mendelian Randomization Analysis. JAMA Cardiol. 2019, 4, 575-579. [CrossRef]

23. Kronenberg, F. Therapeutic lowering of lipoprotein(a): How much is enough? Atherosclerosis 2019, 288, 163-165. [CrossRef]

24. Julius, U.; Tselmin, S.; Schatz, U.; Fischer, S.; Birkenfeld, A.L.; Bornstein, S.R. Actual situation of lipoprotein apheresis in patients with elevated lipoprotein(a) levels. Atheroscler. Suppl. 2019, 40, 1-7. [CrossRef]

25. Madsen, C.M.; Kamstrup, P.R.; Langsted, A.; Varbo, A.; Nordestgaard, B.G. Lipoprotein(a)-Lowering by 50 $\mathrm{mg} / \mathrm{dL}$ (105 nmol/L) May Be Needed to Reduce Cardiovascular Disease 20\% in Secondary Prevention: A Population-Based Study. Arterioscler. Thromb. Vasc. Biol. 2020, 40, 255-266. [CrossRef]

26. Nordestgaard, B.G.; Chapman, M.J.; Ray, K.; Boren, J.; Andreotti, F.; Watts, G.F.; Ginsberg, H.; Amarenco, P.; Catapano, A.; Descamps, O.S.; et al. Lipoprotein(a) as a cardiovascular risk factor: Current status. Eur. Heart J. 2010, 31, 2844-2853. [CrossRef] [PubMed]

27. Grundy, S.M.; Stone, N.J.; Bailey, A.L.; Beam, C.; Birtcher, K.K.; Blumenthal, R.S.; Braun, L.T.; de Ferranti, S.; Faiella-Tommasino, J.; Forman, D.E.; et al. 2018 AHA/ACC/AACVPR/AAPA/ABC/ ACPM/ADA/AGS/APhA/ASPC/NLA/PCNA Guideline on the Management of Blood Cholesterol: A Report of the American College of Cardiology/American Heart Association Task Force on Clinical Practice Guidelines. Circulation 2019, 139, e1082-e1143. [CrossRef]

28. Mach, F.; Baigent, C.; Catapano, A.L.; Koskinas, K.C.; Casula, M.; Badimon, L.; Chapman, M.J.; De Backer, G.G.; Delgado, V.; Ference, B.A.; et al. 2019 ESC/EAS Guidelines for the management of dyslipidaemias: Lipid modification to reduce cardiovascular risk. Eur. Heart J. 2020, 41, 111-188. [CrossRef]

29. Guan, W.; Cao, J.; Steffen, B.T.; Post, W.S.; Stein, J.H.; Tattersall, M.C.; Kaufman, J.D.; McConnell, J.P.; Hoefner, D.M.; Warnick, R.; et al. Race is a key variable in assigning lipoprotein(a) cutoff values for coronary heart disease risk assessment: The Multi-Ethnic Study of Atherosclerosis. Arterioscler. Thromb. Vasc. Biol. 2015, 35, 996-1001. [CrossRef]

30. Boffa, M.B.; Koschinsky, M.L. Lipoprotein (a): Truly a direct prothrombotic factor in cardiovascular disease? J. Lipid Res. 2016, 57, 745-757. [CrossRef]

31. Brown, M.S.; Goldstein, J.L. Plasma lipoproteins: Teaching old dogmas new tricks. Nature 1987, 330, $113-114$. [CrossRef] [PubMed]

32. Ghiselli, G.; Gaddi, A.; Barozzi, G.; Ciarrocchi, A.; Descovich, G. Plasma lipoprotein(a) concentration in familial hypercholesterolemic patients without coronary artery disease. Metabolism 1992, 41, 833-838. [CrossRef]

33. Dahlen, G.H.; Weinehall, L.; Stenlund, H.; Jansson, J.H.; Hallmans, G.; Huhtasaari, F.; Wall, S. Lipoprotein(a) and cholesterol levels act synergistically and apolipoprotein A-I is protective for the incidence of primary acute myocardial infarction in middle-aged males. An incident case-control study from Sweden. J. Intern. Med. 1998, 244, 425-430. [CrossRef] [PubMed]

34. Langsted, A.; Kamstrup, P.R.; Nordestgaard, B.G. High lipoprotein(a) and high risk of mortality. Eur. Heart J. 2019, 40, 2760-2770. [CrossRef]

35. Langsted, A.; Kamstrup, P.R.; Nordestgaard, B.G. Response to 'Lipoprotein(a): It is not the cholesterol content: It is the apolipoprotein(a)!'. Eur. Heart J. 2019, 40, 3577. [CrossRef]

36. Chan, D.C.; Pang, J.; Hooper, A.J.; Bell, D.A.; Burnett, J.R.; Watts, G.F. Effect of Lipoprotein(a) on the Diagnosis of Familial Hypercholesterolemia: Does It Make a Difference in the Clinic? Clin. Chem. 2019, 65, 1258-1266. [CrossRef]

37. Nordestgaard, B.G.; Langsted, A. Lipoprotein (a) as a cause of cardiovascular disease: Insights from epidemiology, genetics, and biology. J. Lipid Res. 2016, 57, 1953-1975. [CrossRef]

38. Ellis, K.L.; Pang, J.; Chieng, D.; Bell, D.A.; Burnett, J.R.; Schultz, C.J.; Hillis, G.S.; Watts, G.F. Elevated lipoprotein(a) and familial hypercholesterolemia in the coronary care unit: Between Scylla and Charybdis. Clin. Cardiol. 2018, 41, 378-384. [CrossRef] [PubMed]

39. Pavanello, C.; Pirazzi, C.; Bjorkman, K.; Sandstedt, J.; Tarlarini, C.; Mosca, L.; Romeo, S.; Calabresi, L.; Mancina, R.M. Individuals with familial hypercholesterolemia and cardiovascular events have higher circulating Lp(a) levels. J. Clin. Lipidol. 2019, 13, 778-787. [CrossRef] [PubMed] 
40. Larsson, S.C.; Gill, D.; Mason, A.M.; Jiang, T.; Back, M.; Butterworth, A.S.; Burgess, S. Lipoprotein(a) in Alzheimer, Atherosclerotic, Cerebrovascular, Thrombotic, and Valvular Disease: Mendelian Randomization Investigation. Circulation 2020, 141, 1826-1828. [CrossRef] [PubMed]

41. Thanassoulis, G.; Campbell, C.Y.; Owens, D.S.; Smith, J.G.; Smith, A.V.; Peloso, G.M.; Kerr, K.F.; Pechlivanis, S.; Budoff, M.J.; Harris, T.B.; et al. Genetic associations with valvular calcification and aortic stenosis. N. Engl. J. Med. 2013, 368, 503-512. [CrossRef] [PubMed]

42. Ferretti, G.; Bacchetti, T.; Johnston, T.P.; Banach, M.; Pirro, M.; Sahebkar, A. Lipoprotein(a): A missing culprit in the management of athero-thrombosis? J. Cell. Physiol. 2018, 233, 2966-2981. [CrossRef] [PubMed]

43. Kamstrup, P.R.; Nordestgaard, B.G. Elevated Lipoprotein(a) Levels, LPA Risk Genotypes, and Increased Risk of Heart Failure in the General Population. JACC Heart Fail. 2016, 4, 78-87. [CrossRef]

44. Golledge, J.; Rowbotham, S.; Velu, R.; Quigley, F.; Jenkins, J.; Bourke, M.; Bourke, B.; Thanigaimani, S.; Chan, D.C.; Watts, G.F. Association of Serum Lipoprotein (a) With the Requirement for a Peripheral Artery Operation and the Incidence of Major Adverse Cardiovascular Events in People With Peripheral Artery Disease. J. Am. Heart Assoc. 2020, 9, e015355. [CrossRef]

45. Youssef, A.; Clark, J.R.; Koschinsky, M.L.; Boffa, M.B. Lipoprotein(a): Expanding Our Knowledge of Aortic Valve Narrowing. Trends Cardiovasc. Med. 2020. [CrossRef]

46. Guddeti, R.R.; Patil, S.; Ahmed, A.; Sharma, A.; Aboeata, A.; Lavie, C.J.; Alla, V.M. Lipoprotein(a) and calcific aortic valve stenosis: A systematic review. Prog. Cardiovasc. Dis. 2020. [CrossRef] [PubMed]

47. Yahya, R.; Berk, K.; Verhoeven, A.; Bos, S.; van der Zee, L.; Touw, J.; Erhart, G.; Kronenberg, F.; Timman, R.; Sijbrands, E.; et al. Statin treatment increases lipoprotein(a) levels in subjects with low molecular weight apolipoprotein(a) phenotype. Atherosclerosis 2019, 289, 201-205. [CrossRef]

48. Tsimikas, S.; Gordts, P.; Nora, C.; Yeang, C.; Witztum, J.L. Statin therapy increases lipoprotein(a) levels. Eur. Heart J. 2019. [CrossRef]

49. Pirillo, A.; Catapano, A.L. Statins increase Lp(a) plasma level: Is this clinically relevant? Eur. Heart J. 2019. [CrossRef]

50. Chennamsetty, I.; Claudel, T.; Kostner, K.M.; Baghdasaryan, A.; Kratky, D.; Levak-Frank, S.; Frank, S.; Gonzalez, F.J.; Trauner, M.; Kostner, G.M. Farnesoid X receptor represses hepatic human APOA gene expression. J. Clin. Investig. 2011, 121, 3724-3734. [CrossRef]

51. Banach, M.; Penson, P.E. Statins and Lp(a): Do not make perfect the enemy of excellent. Eur. Heart J. 2020, 41, 190-191. [CrossRef] [PubMed]

52. Tsimikas, S.; Gordts, P.; Nora, C.; Yeang, C.; Witztum, J.L. Statins and increases in Lp(a): An inconvenient truth that needs attention. Eur. Heart J. 2020, 41, 192-193. [CrossRef] [PubMed]

53. Ma, L.; Chan, D.C.; Ooi, E.M.M.; Marcovina, S.M.; Barrett, P.H.R.; Watts, G.F. Apolipoprotein(a) Kinetics in Statin-Treated Patients With Elevated Plasma Lipoprotein(a) Concentration. J. Clin. Endocrinol. Metab. 2019, 104, 6247-6255. [CrossRef]

54. Nandakumar, R.; Matveyenko, A.; Thomas, T.; Pavlyha, M.; Ngai, C.; Holleran, S.; Ramakrishnan, R.; Ginsberg, H.N.; Karmally, W.; Marcovina, S.M.; et al. Effects of mipomersen, an apolipoprotein B100 antisense, on lipoprotein (a) metabolism in healthy subjects. J. Lipid Res. 2018, 59, 2397-2402. [CrossRef]

55. McCormick, S.P.A.; Schneider, W.J. Lipoprotein(a) catabolism: A case of multiple receptors. Pathology 2019, 51, 155-164. [CrossRef]

56. Willeit, P.; Ridker, P.M.; Nestel, P.J.; Simes, J.; Tonkin, A.M.; Pedersen, T.R.; Schwartz, G.G.; Olsson, A.G.; Colhoun, H.M.; Kronenberg, F.; et al. Baseline and on-statin treatment lipoprotein(a) levels for prediction of cardiovascular events: Individual patient-data meta-analysis of statin outcome trials. Lancet 2018, 392, 1311-1320. [CrossRef]

57. Chennamsetty, I.; Kostner, K.M.; Claudel, T.; Vinod, M.; Frank, S.; Weiss, T.S.; Trauner, M.; Kostner, G.M. Nicotinic acid inhibits hepatic APOA gene expression: Studies in humans and in transgenic mice. J. Lipid Res. 2012, 53, 2405-2412. [CrossRef]

58. Carlson, L.A.; Hamsten, A.; Asplund, A. Pronounced lowering of serum levels of lipoprotein Lp(a) in hyperlipidaemic subjects treated with nicotinic acid. J. Intern. Med. 1989, 226, 271-276. [CrossRef]

59. Noma, A.; Maeda, S.; Okuno, M.; Abe, A.; Muto, Y. Reduction of serum lipoprotein(a) levels in hyperlipidaemic patients with alpha-tocopheryl nicotinate. Atherosclerosis 1990, 84, 213-217. [CrossRef] 
60. Sano, R.; Fujino, A.; Saito, T.; Takenaka, K.; Yahata, Y.; Ogyu, A.; Toyota, T. Reduction by niceritrol treatment of serum lipoprotein(a) in normolipidemic patients with coronary artery disease. Tohoku J. Exp. Med. 1993, 169, 299-307. [CrossRef]

61. Seed, M.; O'Connor, B.; Perombelon, N.; O’Donnell, M.; Reaveley, D.; Knight, B.L. The effect of nicotinic acid and acipimox on lipoprotein(a) concentration and turnover. Atherosclerosis 1993, 101, 61-68. [CrossRef]

62. Parish, S.; Hopewell, J.C.; Hill, M.R.; Marcovina, S.; Valdes-Marquez, E.; Haynes, R.; Offer, A.; Pedersen, T.R.; Baigent, C.; Collins, R.; et al. Impact of Apolipoprotein(a) Isoform Size on Lipoprotein(a) Lowering in the HPS2-THRIVE Study. Circ. Genom. Precis. Med. 2018, 11, e001696. [CrossRef]

63. Cenarro, A.; Puzo, J.; Ferrando, J.; Mateo-Gallego, R.; Bea, A.M.; Calmarza, P.; Jarauta, E.; Civeira, F. Effect of Nicotinic acid/Laropiprant in the lipoprotein(a) concentration with regard to baseline lipoprotein(a) concentration and LPA genotype. Metabolism 2014, 63, 365-371. [CrossRef]

64. Warden, B.A.; Minnier, J.; Watts, G.F.; Fazio, S.; Shapiro, M.D. Impact of PCSK9 inhibitors on plasma lipoprotein(a) concentrations with or without a background of niacin therapy. J. Clin. Lipidol. 2019, 13, 580-585. [CrossRef]

65. Khera, A.V.; Everett, B.M.; Caulfield, M.P.; Hantash, F.M.; Wohlgemuth, J.; Ridker, P.M.; Mora, S. Lipoprotein(a) concentrations, rosuvastatin therapy, and residual vascular risk: An analysis from the JUPITER Trial (Justification for the Use of Statins in Prevention: An Intervention Trial Evaluating Rosuvastatin). Circulation 2014, 129, 635-642. [CrossRef] [PubMed]

66. Zenti, M.G.; Altomari, A.; Lupo, M.G.; Botta, M.; Bonora, E.; Corsini, A.; Ruscica, M.; Ferri, N. From lipoprotein apheresis to proprotein convertase subtilisin/kexin type 9 inhibitors: Impact on low-density lipoprotein cholesterol and C-reactive protein levels in cardiovascular disease patients. Eur. J. Prev. Cardiol. 2018, 25, 1843-1851. [CrossRef] [PubMed]

67. Macchi, C.; Banach, M.; Corsini, A.; Sirtori, C.R.; Ferri, N.; Ruscica, M. Changes in circulating pro-protein convertase subtilisin/kexin type 9 levels - experimental and clinical approaches with lipid-lowering agents. Eur. J. Prev. Cardiol. 2019, 26, 930-949. [CrossRef]

68. Liberopoulos, E. Lipoprotein(a) reduction with proprotein convertase subtilisin/kexin type 9 inhibitors: An unsolved mystery. Eur. J. Prev. Cardiol. 2020. [CrossRef]

69. Croyal, M.; Blanchard, V.; Ouguerram, K.; Chetiveaux, M.; Cabioch, L.; Moyon, T.; Billon-Crossouard, S.; Aguesse, A.; Bernardeau, K.; Le May, C.; et al. VLDL (Very-Low-Density Lipoprotein)-Apo E (Apolipoprotein E) May Influence Lp(a) (Lipoprotein [a]) Synthesis or Assembly. Arterioscler. Thromb. Vasc. Biol. 2020, 40, 819-829. [CrossRef]

70. Blanchard, V.; Ramin-Mangata, S.; Billon-Crossouard, S.; Aguesse, A.; Durand, M.; Chemello, K.; Nativel, B.; Flet, L.; Chetiveaux, M.; Jacobi, D.; et al. Kinetics of plasma apolipoprotein E isoforms by LC-MS/MS: A pilot study. J. Lipid Res. 2018, 59, 892-900. [CrossRef]

71. Raal, F.J.; Giugliano, R.P.; Sabatine, M.S.; Koren, M.J.; Langslet, G.; Bays, H.; Blom, D.; Eriksson, M.; Dent, R.; Wasserman, S.M.; et al. Reduction in lipoprotein(a) with PCSK9 monoclonal antibody evolocumab (AMG 145): A pooled analysis of more than 1300 patients in 4 phase II trials. J. Am. Coll. Cardiol. 2014, 63, 1278-1288. [CrossRef]

72. Watts, G.F.; Chan, D.C.; Somaratne, R.; Wasserman, S.M.; Scott, R.; Marcovina, S.M.; Barrett, P.H.R. Controlled study of the effect of proprotein convertase subtilisin-kexin type 9 inhibition with evolocumab on lipoprotein(a) particle kinetics. Eur. Heart J. 2018, 39, 2577-2585. [CrossRef]

73. Reyes-Soffer, G.; Pavlyha, M.; Ngai, C.; Thomas, T.; Holleran, S.; Ramakrishnan, R.; Karmally, W.; Nandakumar, R.; Fontanez, N.; Obunike, J.; et al. Effects of PCSK9 Inhibition With Alirocumab on Lipoprotein Metabolism in Healthy Humans. Circulation 2017, 135, 352-362. [CrossRef] [PubMed]

74. Watts, G.F.; Gidding, S.S.; Mata, P.; Pang, J.; Sullivan, D.R.; Yamashita, S.; Raal, F.J.; Santos, R.D.; Ray, K.K. Familial hypercholesterolaemia: Evolving knowledge for designing adaptive models of care. Nat. Rev. Cardiol. 2020. [CrossRef]

75. Mefford, M.T.; Marcovina, S.M.; Bittner, V.; Cushman, M.; Brown, T.M.; Farkouh, M.E.; Tsimikas, S.; Monda, K.L.; Lopez, J.A.G.; Muntner, P.; et al. PCSK9 loss-of-function variants and Lp(a) phenotypes among black US adults. J. Lipid Res. 2019, 60, 1946-1952. [CrossRef]

76. Villard, E.F.; Thedrez, A.; Blankenstein, J.; Croyal, M.; Tran, T.T.; Poirier, B.; Le Bail, J.C.; Illiano, S.; Nobecourt, E.; Krempf, M.; et al. PCSK9 Modulates the Secretion But Not the Cellular Uptake of Lipoprotein(a) Ex Vivo: An Effect Blunted by Alirocumab. JACC Basic Transl. Sci. 2016, 1, 419-427. [CrossRef] 
77. Tavori, H.; Christian, D.; Minnier, J.; Plubell, D.; Shapiro, M.D.; Yeang, C.; Giunzioni, I.; Croyal, M.; Duell, P.B.; Lambert, G.; et al. PCSK9 Association With Lipoprotein(a). Circ. Res. 2016, 119, 29-35. [CrossRef]

78. Romagnuolo, R.; Scipione, C.A.; Boffa, M.B.; Marcovina, S.M.; Seidah, N.G.; Koschinsky, M.L. Lipoprotein(a) catabolism is regulated by proprotein convertase subtilisin/kexin type 9 through the low density lipoprotein receptor. J. Biol. Chem. 2015, 290, 11649-11662. [CrossRef]

79. Viney, N.J.; Yeang, C.; Yang, X.; Xia, S.; Witztum, J.L.; Tsimikas, S. Relationship between “LDL-C”, estimated true LDL-C, apolipoprotein B-100, and PCSK9 levels following lipoprotein(a) lowering with an antisense oligonucleotide. J. Clin. Lipidol. 2018, 12, 702-710. [CrossRef]

80. Toth, P.P. PCSK9 and Lipoprotein(a): The Plot Thickens. Circ. Res. 2016, 119, 3-6. [CrossRef]

81. Ruscica, M.; Simonelli, S.; Botta, M.; Ossoli, A.; Lupo, M.G.; Magni, P.; Corsini, A.; Arca, M.; Pisciotta, L.; Veglia, F.; et al. Plasma PCSK9 levels and lipoprotein distribution are preserved in carriers of genetic HDL disorders. Biochim. Biophys. Acta Mol. Cell Biol. Lipids 2018, 1863, 991-997. [CrossRef]

82. Bittner, V.A.; Szarek, M.; Aylward, P.E.; Bhatt, D.L.; Diaz, R.; Edelberg, J.M.; Fras, Z.; Goodman, S.G.; Halvorsen, S.; Hanotin, C.; et al. Effect of Alirocumab on Lipoprotein(a) and Cardiovascular Risk After Acute Coronary Syndrome. J. Am. Coll. Cardiol. 2020, 75, 133-144. [CrossRef] [PubMed]

83. Mora, S. Lp(a)'s Odyssey: Should We Measure Lp(a) Post-ACS and What Should We Do With the Results? J. Am. Coll. Cardiol. 2020, 75, 145-147. [CrossRef] [PubMed]

84. O’Donoghue, M.L.; Fazio, S.; Giugliano, R.P.; Stroes, E.S.G.; Kanevsky, E.; Gouni-Berthold, I.; Im, K.; Lira Pineda, A.; Wasserman, S.M.; Ceska, R.; et al. Lipoprotein(a), PCSK9 Inhibition, and Cardiovascular Risk. Circulation 2019, 139, 1483-1492. [CrossRef] [PubMed]

85. Ray, K.K.; Vallejo-Vaz, A.J.; Ginsberg, H.N.; Davidson, M.H.; Louie, M.J.; Bujas-Bobanovic, M.; Minini, P.; Eckel, R.H.; Cannon, C.P. Lipoprotein(a) reductions from PCSK9 inhibition and major adverse cardiovascular events: Pooled analysis of alirocumab phase 3 trials. Atherosclerosis 2019, 288, 194-202. [CrossRef]

86. Bergmark, B.A.; O’Donoghue, M.L.; Murphy, S.A.; Kuder, J.F.; Ezhov, M.V.; Ceska, R.; Gouni-Berthold, I.; Jensen, H.K.; Tokgozoglu, S.L.; Mach, F.; et al. An Exploratory Analysis of Proprotein Convertase Subtilisin/Kexin Type 9 Inhibition and Aortic Stenosis in the FOURIER Trial. JAMA Cardiol. 2020. [CrossRef]

87. Langsted, A.; Nordestgaard, B.G.; Benn, M.; Tybjaerg-Hansen, A.; Kamstrup, P.R. PCSK9 R46L Loss-of-Function Mutation Reduces Lipoprotein(a), LDL Cholesterol, and Risk of Aortic Valve Stenosis. J. Clin. Endocrinol. Metab. 2016, 101, 3281-3287. [CrossRef] [PubMed]

88. Stiekema, L.C.A.; Stroes, E.S.G.; Verweij, S.L.; Kassahun, H.; Chen, L.; Wasserman, S.M.; Sabatine, M.S.; Mani, V.; Fayad, Z.A. Persistent arterial wall inflammation in patients with elevated lipoprotein(a) despite strong low-density lipoprotein cholesterol reduction by proprotein convertase subtilisin/kexin type 9 antibody treatment. Eur. Heart J. 2019, 40, 2775-2781. [CrossRef] [PubMed]

89. Ray, K.K.; Stoekenbroek, R.M.; Kallend, D.; Leiter, L.A.; Landmesser, U.; Wright, R.S.; Wijngaard, P.; Kastelein, J.J.P. Effect of an siRNA Therapeutic Targeting PCSK9 on Atherogenic Lipoproteins. Circulation 2018, 138, 1304-1316. [CrossRef]

90. Ray, K.K.; Wright, R.S.; Kallend, D.; Koenig, W.; Leiter, L.A.; Raal, F.J.; Bisch, J.A.; Richardson, T.; Jaros, M.; Wijngaard, P.L.J.; et al. Two Phase 3 Trials of Inclisiran in Patients with Elevated LDL Cholesterol. N. Engl. J. Med. 2020. [CrossRef]

91. Raal, F.J.; Kallend, D.; Ray, K.K.; Turner, T.; Koenig, W.; Wright, R.S.; Wijngaard, P.L.J.; Curcio, D.; Jaros, M.J.; Leiter, L.A.; et al. Inclisiran for the Treatment of Heterozygous Familial Hypercholesterolemia. N. Engl. J. Med. 2020. [CrossRef] [PubMed]

92. Tenenbaum, A.; Fisman, E.Z. Balanced pan-PPAR activator bezafibrate in combination with statin: Comprehensive lipids control and diabetes prevention? Cardiovasc. Diabetol. 2012, 11, 140. [CrossRef] [PubMed]

93. Maggi, F.M.; Biasi, G.M.; Catapano, A.L. Reduction of Lp(a) plasma levels by bezafibrate. Atherosclerosis 1993, 100, 127-128. [CrossRef]

94. Fereshetian, A.G.; Davidson, M.; Haber, H.; Black, D.M. Gemfibrozil treatment in patients with elevated lipoprotein a: A pilot study. Clin. Drug Investig. 1998, 16, 1-7. [CrossRef] [PubMed]

95. Eckardstein, A.V. Lipoprotein(a). Eur. Heart J. 2017, 38, 1530-1532. [CrossRef] [PubMed] 
96. Sahebkar, A.; Simental-Mendia, L.E.; Watts, G.F.; Serban, M.C.; Banach, M. Lipid and Blood Pressure Meta-analysis Collaboration, G. Comparison of the effects of fibrates versus statins on plasma lipoprotein(a) concentrations: A systematic review and meta-analysis of head-to-head randomized controlled trials. BMC Med. 2017, 15, 22. [CrossRef]

97. Rath, M.; Pauling, L. Hypothesis: Lipoprotein(a) is a surrogate for ascorbate. Proc. Natl. Acad. Sci. USA 1990, 87, 6204-6207. [CrossRef]

98. Jenner, J.L.; Jacques, P.F.; Seman, L.J.; Schaefer, E.J. Ascorbic acid supplementation does not lower plasma lipoprotein(a) concentrations. Atherosclerosis 2000, 151, 541-544. [CrossRef]

99. Farish, E.; Rolton, H.A.; Barnes, J.F.; Hart, D.M. Lipoprotein (a) concentrations in postmenopausal women taking norethisterone. BMJ 1991, 303, 694. [CrossRef]

100. Farish, E.; Rolton, H.A.; Barnes, J.F.; Fletcher, C.D.; Walsh, D.J.; Spowart, K.J.; Hart, D.M. Lipoprotein(a) and postmenopausal oestrogen. Acta Endocrinol. (Copenh) 1993, 129, 225-228. [CrossRef]

101. Espeland, M.A.; Marcovina, S.M.; Miller, V.; Wood, P.D.; Wasilauskas, C.; Sherwin, R.; Schrott, H.; Bush, T.L. Effect of postmenopausal hormone therapy on lipoprotein(a) concentration. PEPI Investigators. Postmenopausal Estrogen/Progestin Interventions. Circulation 1998, 97, 979-986. [CrossRef] [PubMed]

102. Hulley, S.; Grady, D.; Bush, T.; Furberg, C.; Herrington, D.; Riggs, B.; Vittinghoff, E. Randomized trial of estrogen plus progestin for secondary prevention of coronary heart disease in postmenopausal women. Heart and Estrogen/progestin Replacement Study (HERS) Research Group. JAMA 1998, 280, 605-613. [CrossRef] [PubMed]

103. Shewmon, D.A.; Stock, J.L.; Abusamra, L.C.; Kristan, M.A.; Baker, S.; Heiniluoma, K.M. Tamoxifen decreases lipoprotein (a) in patients with breast cancer. Metabolism 1994, 43, 531-532. [CrossRef]

104. Albers, J.J.; Taggart, H.M.; Applebaum-Bowden, D.; Haffner, S.; Chesnut, C.H., III; Hazzard, W.R. Reduction of lecithin-cholesterol acyltransferase, apolipoprotein D and the Lp(a) lipoprotein with the anabolic steroid stanozolol. Biochim. Biophys. Acta 1984, 795, 293-296. [CrossRef]

105. Crook, D.; Sidhu, M.; Seed, M.; O’Donnell, M.; Stevenson, J.C. Lipoprotein Lp(a) levels are reduced by danazol, an anabolic steroid. Atherosclerosis 1992, 92, 41-47. [CrossRef]

106. Thompson, G.; Parhofer, K.G. Current Role of Lipoprotein Apheresis. Curr. Atheroscler. Rep. 2019, $21,26$. [CrossRef]

107. Cuchel, M.; Bruckert, E.; Ginsberg, H.N.; Raal, F.J.; Santos, R.D.; Hegele, R.A.; Kuivenhoven, J.A.; Nordestgaard, B.G.; Descamps, O.S.; Steinhagen-Thiessen, E.; et al. Homozygous familial hypercholesterolaemia: New insights and guidance for clinicians to improve detection and clinical management. A position paper from the Consensus Panel on Familial Hypercholesterolaemia of the European Atherosclerosis Society. Eur. Heart J. 2014, 35, 2146-2157. [CrossRef]

108. Wang, A.; Richhariya, A.; Gandra, S.R.; Calimlim, B.; Kim, L.; Quek, R.G.; Nordyke, R.J.; Toth, P.P. Systematic Review of Low-Density Lipoprotein Cholesterol Apheresis for the Treatment of Familial Hypercholesterolemia. J. Am. Heart Assoc. 2016, 5. [CrossRef]

109. Leebmann, J.; Roeseler, E.; Julius, U.; Heigl, F.; Spitthoever, R.; Heutling, D.; Breitenberger, P.; Maerz, W.; Lehmacher, W.; Heibges, A.; et al. Lipoprotein apheresis in patients with maximally tolerated lipid-lowering therapy, lipoprotein(a)-hyperlipoproteinemia, and progressive cardiovascular disease: Prospective observational multicenter study. Circulation 2013, 128, 2567-2576. [CrossRef]

110. Rosada, A.; Kassner, U.; Vogt, A.; Willhauck, M.; Parhofer, K.; Steinhagen-Thiessen, E. Does regular lipid apheresis in patients with isolated elevated lipoprotein(a) levels reduce the incidence of cardiovascular events? Artif. Organs 2014, 38, 135-141. [CrossRef]

111. Bigazzi, F.; Sbrana, F.; Berretti, D.; Maria Grazia, Z.; Zambon, S.; Fabris, A.; Fonda, M.; Vigna, G.B.; D'Alessandri, G.; Passalacqua, S.; et al. Reduced incidence of cardiovascular events in hyper-Lp(a) patients on lipoprotein apheresis. The G.I.L.A. (Gruppo Interdisciplinare Aferesi Lipoproteica) pilot study. Transfus. Apher. Sci. 2018, 57, 661-664. [CrossRef] [PubMed]

112. Von Dryander, M.; Fischer, S.; Passauer, J.; Muller, G.; Bornstein, S.R.; Julius, U. Differences in the atherogenic risk of patients treated by lipoprotein apheresis according to their lipid pattern. Atheroscler. Suppl. 2013, 14, 39-44. [CrossRef] [PubMed]

113. Emmrich, U.; Hohenstein, B.; Julius, U. Actual situation of lipoprotein apheresis in Saxony in 2013. Atheroscler. Suppl. 2015, 18, 215-225. [CrossRef] [PubMed] 
114. Heigl, F.; Hettich, R.; Lotz, N.; Reeg, H.; Pflederer, T.; Osterkorn, D.; Osterkorn, K.; Klingel, R. Efficacy, safety, and tolerability of long-term lipoprotein apheresis in patients with LDL- or Lp(a) hyperlipoproteinemia: Findings gathered from more than 36,000 treatments at one center in Germany. Atheroscler. Suppl. 2015, 18, 154-162. [CrossRef] [PubMed]

115. Schatz, U.; Tselmin, S.; Muller, G.; Julius, U.; Hohenstein, B.; Fischer, S.; Bornstein, S.R. Most significant reduction of cardiovascular events in patients undergoing lipoproteinapheresis due to raised Lp(a) levels-A multicenter observational study. Atheroscler. Suppl. 2017, 30, 246-252. [CrossRef]

116. Daida, H.; Yamaguchi, H. Clinical application and effectiveness of low-density lipoprotein apheresis in the treatment of coronary artery disease. Ther. Apher. 1997, 1, 253-254. [CrossRef]

117. Cegla, J.; Neely, R.D.G.; France, M.; Ferns, G.; Byrne, C.D.; Halcox, J.; Datta, D.; Capps, N.; Shoulders, C.; Qureshi, N.; et al. HEART UK consensus statement on Lipoprotein(a): A call to action. Atherosclerosis 2019, 291, 62-70. [CrossRef]

118. Padmanabhan, A.; Connelly-Smith, L.; Aqui, N.; Balogun, R.A.; Klingel, R.; Meyer, E.; Pham, H.P.; Schneiderman, J.; Witt, V.; Wu, Y.; et al. Guidelines on the Use of Therapeutic Apheresis in Clinical Practice-Evidence-Based Approach from the Writing Committee of the American Society for Apheresis: The Eighth Special Issue. J. Clin. Apher. 2019, 34, 171-354. [CrossRef] [PubMed]

119. Santos, R.D.; Gidding, S.S.; Hegele, R.A.; Cuchel, M.A.; Barter, P.J.; Watts, G.F.; Baum, S.J.; Catapano, A.L.; Chapman, M.J.; Defesche, J.C.; et al. Defining severe familial hypercholesterolaemia and the implications for clinical management: A consensus statement from the International Atherosclerosis Society Severe Familial Hypercholesterolemia Panel. Lancet Diabetes Endocrinol. 2016, 4, 850-861. [CrossRef]

120. Raina, R.; Young, C.; Krishnappa, V.; Chanchlani, R. Role of Lipoprotein Apheresis in Cardiovascular Disease Risk Reduction. Blood Purif. 2019, 47, 301-316. [CrossRef] [PubMed]

121. Stefanutti, C.; Julius, U.; Watts, G.F.; Harada-Shiba, M.; Cossu, M.; Schettler, V.J.; De Silvestro, G.; Soran, H.; Van Lennep, J.R.; Pisciotta, L.; et al. Toward an international consensus-Integrating lipoprotein apheresis and new lipid-lowering drugs. J. Clin. Lipidol. 2017, 11, 858-871. [CrossRef] [PubMed]

122. Thompson, G.R. Lipoprotein apheresis. Curr. Opin. Lipidol. 2010, 21, 487-491. [CrossRef] [PubMed]

123. Julius, U. Lipoprotein apheresis in the management of severe hypercholesterolemia and of elevation of lipoprotein(a): Current perspectives and patient selection. Med. Devices (Auckl) 2016, 9, 349-360. [CrossRef] [PubMed]

124. Moriarty, P.M. Low-density liporpotein apheresis. In Clinical Lipidology: A Companion to Braunwald's Heart Disease, 1st ed.; Elsevier: Amsterdam, The Netherlands, 2009; p. 363.

125. Julius, U.; Fischer, S.; Schatz, U.; Hohenstein, B.; Bornstein, S.R. Lipoprotein apheresis: An update. Clin. Lipidol. 2013, 8, 13. [CrossRef]

126. Thompson, G.R. LDL apheresis. Atherosclerosis 2003, 167, 1-13. [CrossRef]

127. Stefanutti, C.; Thompson, G.R. Lipoprotein apheresis in the management of familial hypercholesterolaemia: Historical perspective and recent advances. Curr. Atheroscler. Rep. 2015, 17, 465. [CrossRef]

128. Waldmann, E.; Parhofer, K.G. Lipoprotein apheresis to treat elevated lipoprotein (a). J. Lipid Res. 2016, 57, 1751-1757. [CrossRef]

129. Thompson, G.R.; Maher, V.M.; Matthews, S.; Kitano, Y.; Neuwirth, C.; Shortt, M.B.; Davies, G.; Rees, A.; Mir, A.; Prescott, R.J.; et al. Familial Hypercholesterolaemia Regression Study: A randomised trial of low-density-lipoprotein apheresis. Lancet 1995, 345, 811-816. [CrossRef]

130. Gross, E.; Hohenstein, B.; Julius, U. Effects of Lipoprotein apheresis on the Lipoprotein(a) levels in the long run. Atheroscler. Suppl. 2015, 18, 226-232. [CrossRef]

131. Kassner, U.; Vogt, A.; Rosada, A.; Barz, F.; Giannakidou-Jordan, E.; Berthold, H.K.; Steinhagen-Thiessen, E. Designing a study to evaluate the effect of apheresis in patients with elevated lipoprotein(a). Atheroscler. Suppl. 2009, 10, 85-88. [CrossRef]

132. Moriarty, P.M.; Parhofer, K.G.; Babirak, S.P.; de Goma, E.; Duell, P.B.; Hohenstein, B.; Ramlow, W.; Simha, V.; Steinhagen-Thiessen, E.; Thompson, P.D.; et al. Alirocumab in patients with heterozygous familial hypercholesterolemia undergoing lipoprotein apheresis: Rationale and design of the ODYSSEY ESCAPE trial. J. Clin. Lipidol. 2016, 10, 627-634. [CrossRef] [PubMed] 
133. Moriarty, P.M.; Parhofer, K.G.; Babirak, S.P.; Cornier, M.A.; Duell, P.B.; Hohenstein, B.; Leebmann, J.; Ramlow, W.; Schettler, V.; Simha, V.; et al. Alirocumab in patients with heterozygous familial hypercholesterolaemia undergoing lipoprotein apheresis: The ODYSSEY ESCAPE trial. Eur. Heart J. 2016, 37, 3588-3595. [CrossRef] [PubMed]

134. Santos, R.D.; Stein, E.A.; Hovingh, G.K.; Blom, D.J.; Soran, H.; Watts, G.F.; Lopez, J.A.G.; Bray, S.; Kurtz, C.E.; Hamer, A.W.; et al. Long-Term Evolocumab in Patients With Familial Hypercholesterolemia. J. Am. Coll. Cardiol. 2020, 75, 565-574. [CrossRef] [PubMed]

135. Baum, S.J.; Sampietro, T.; Datta, D.; Moriarty, P.M.; Knusel, B.; Schneider, J.; Somaratne, R.; Kurtz, C.; Hohenstein, B. Effect of evolocumab on lipoprotein apheresis requirement and lipid levels: Results of the randomized, controlled, open-label DE LAVAL study. J. Clin. Lipidol. 2019, 13, 901-909. [CrossRef]

136. Torres, E.; Goicoechea, M.; Hernandez, A.; Rodriguez Ferrero, M.L.; Garcia, A.; Macias, N.; Anaya, F. Efficacy of Evolocumab vs low-density lipoprotein cholesterol apheresis in patients with familial hypercholesterolemia and high cardiovascular risk (EVOLAFER01). J. Clin. Apher. 2020, 35, 9-17. [CrossRef]

137. Tselmin, S.; Julius, U.; Weinert, N.; Bornstein, S.R.; Schatz, U. Experience with proprotein convertase subtilisin/kexine type 9 inhibitors (PCSK9i) in patients undergoing lipoprotein apheresis. Atheroscler. Suppl. 2019, 40, 38-43. [CrossRef]

138. Empen, K.; Otto, C.; Brodl, U.C.; Parhofer, K.G. The effects of three different LDL-apheresis methods on the plasma concentrations of E-selectin, VCAM-1, and ICAM-1. J. Clin. Apher. 2002, 17, 38-43. [CrossRef]

139. Kobayashi, S.; Moriya, H.; Maesato, K.; Okamoto, K.; Ohtake, T. LDL-apheresis improves peripheral arterial occlusive disease with an implication for anti-inflammatory effects. J. Clin. Apher. 2005, 20, 239-243. [CrossRef]

140. Moriarty, P.M.; Gibson, C.A. Effect of low-density lipoprotein apheresis on lipoprotein-associated phospholipase A2. Am. J. Cardiol. 2005, 95, 1246-1247. [CrossRef]

141. Wang, Y.; Blessing, F.; Walli, A.K.; Uberfuhr, P.; Fraunberger, P.; Seidel, D. Effects of heparin-mediated extracorporeal low-density lipoprotein precipitation beyond lowering proatherogenic lipoproteins-reduction of circulating proinflammatory and procoagulatory markers. Atherosclerosis 2004, 175, 145-150. [CrossRef]

142. Aengevaeren, W.R.; Kroon, A.A.; Stalenhoef, A.F.; Uijen, G.J.; van der Werf, T. Low density lipoprotein apheresis improves regional myocardial perfusion in patients with hypercholesterolemia and extensive coronary artery disease. LDL-Apheresis Atherosclerosis Regression Study (LAARS). J. Am. Coll. Cardiol. 1996, 28, 1696-1704. [CrossRef]

143. Khan, T.Z.; Hsu, L.Y.; Arai, A.E.; Rhodes, S.; Pottle, A.; Wage, R.; Banya, W.; Gatehouse, P.D.; Giri, S.; Collins, P.; et al. Apheresis as novel treatment for refractory angina with raised lipoprotein(a): A randomized controlled cross-over trial. Eur. Heart J. 2017, 38, 1561-1569. [CrossRef] [PubMed]

144. Sampietro, T.; Sbrana, F.; Pasanisi, E.M.; Bigazzi, F.; Petersen, C.; Coceani, M.; Dal Pino, B.; Ripoli, A.; Pianelli, M.; Luciani, R. LDL apheresis improves coronary flow reserve on the left anterior descending artery in patients with familial hypercholesterolemia and chronic ischemic heart disease. Atheroscler. Suppl. 2017, 30, 135-140. [CrossRef] [PubMed]

145. Bohl, S.; Kassner, U.; Eckardt, R.; Utz, W.; Mueller-Nordhorn, J.; Busjahn, A.; Thomas, H.P.; Abdel-Aty, H.; Klingel, R.; Marcovina, S.; et al. Single lipoprotein apheresis session improves cardiac microvascular function in patients with elevated lipoprotein(a): Detection by stress/rest perfusion magnetic resonance imaging. Ther. Apher. Dial. 2009, 13, 129-137. [CrossRef] [PubMed]

146. Pokrovsky, S.N.; Afanasieva, O.I.; Ezhov, M.V. Lipoprotein(a) apheresis. Curr. Opin. Lipidol. 2016, 27, 351-358. [CrossRef] [PubMed]

147. Ezhov, M.V.; Afanasieva, O.I.; Il'ina, L.N.; Safarova, M.S.; Adamova, I.Y.; Matchin, Y.G.; Konovalov, G.A.; Akchurin, R.S.; Pokrovsky, S.N. Association of lipoprotein(a) level with short- and long-term outcomes after CABG: The role of lipoprotein apheresis. Atheroscler. Suppl. 2017, 30, 187-192. [CrossRef]

148. Tsimikas, S.; Mallat, Z.; Talmud, P.J.; Kastelein, J.J.; Wareham, N.J.; Sandhu, M.S.; Miller, E.R.; Benessiano, J.; Tedgui, A.; Witztum, J.L.; et al. Oxidation-specific biomarkers, lipoprotein(a), and risk of fatal and nonfatal coronary events. J. Am. Coll. Cardiol. 2010, 56, 946-955. [CrossRef]

149. Tellis, C.C.; Tselepis, A.D. The role of lipoprotein-associated phospholipase A2 in atherosclerosis may depend on its lipoprotein carrier in plasma. Biochim. Biophys. Acta 2009, 1791, 327-338. [CrossRef]

150. Macchi, C.; Sirtori, C.R.; Corsini, A.; Santos, R.D.; Watts, G.F.; Ruscica, M. A new dawn for managing dyslipidemias: The era of rna-based therapies. Pharmacol. Res. 2019, 150, 104413. [CrossRef] 
151. Viney, N.J.; van Capelleveen, J.C.; Geary, R.S.; Xia, S.; Tami, J.A.; Yu, R.Z.; Marcovina, S.M.; Hughes, S.G.; Graham, M.J.; Crooke, R.M.; et al. Antisense oligonucleotides targeting apolipoprotein(a) in people with raised lipoprotein(a): Two randomised, double-blind, placebo-controlled, dose-ranging trials. Lancet 2016, 388, 2239-2253. [CrossRef]

152. Tsimikas, S.; Karwatowska-Prokopczuk, E.; Gouni-Berthold, I.; Tardif, J.C.; Baum, S.J.; Steinhagen-Thiessen, E.; Shapiro, M.D.; Stroes, E.S.; Moriarty, P.M.; Nordestgaard, B.G.; et al. Lipoprotein(a) Reduction in Persons with Cardiovascular Disease. N. Engl. J. Med. 2020, 382, 244-255. [CrossRef] [PubMed]

153. Stiekema, L.C.A.; Prange, K.H.M.; Hoogeveen, R.M.; Verweij, S.L.; Kroon, J.; Schnitzler, J.G.; Dzobo, K.E.; Cupido, A.J.; Tsimikas, S.; Stroes, E.S.G.; et al. Potent lipoprotein(a) lowering following apolipoprotein(a) antisense treatment reduces the pro-inflammatory activation of circulating monocytes in patients with elevated lipoprotein(a). Eur. Heart J. 2020. [CrossRef]

154. Julius, U.; Tselmin, S.; Schatz, U.; Fischer, S.; Bornstein, S.R. Lipoprotein(a)-an interdisciplinary challenge. Clin. Res. Cardiol. Suppl. 2019, 14, 20-27. [CrossRef] [PubMed]

155. Awad, K.; Mikhailidis, D.P.; Katsiki, N.; Muntner, P.; Banach, M.; Lipid and Blood Pressure Meta-Analysis Collaboration Group. Effect of Ezetimibe Monotherapy on Plasma Lipoprotein(a) Concentrations in Patients with Primary Hypercholesterolemia: A Systematic Review and Meta-Analysis of Randomized Controlled Trials. Drugs 2018, 78, 453-462. [CrossRef] [PubMed]

156. Gencer, B.; Mach, F. Potential of Lipoprotein(a)-Lowering Strategies in Treating Coronary Artery Disease. Drugs 2020, 80, 229-239. [CrossRef]

157. Ferri, N.; Corsini, A.; Sirtori, C.R.; Ruscica, M. Present therapeutic role of cholesteryl ester transfer protein inhibitors. Pharmacol. Res. 2018, 128, 29-41. [CrossRef]

158. Schrock, C.G. Lipoprotein(a): It is not the cholesterol content: It is the apolipoprotein(a)! Eur. Heart J. 2019, 40, 3576. [CrossRef]

159. Yeang, C.; Witztum, J.L.; Tsimikas, S. 'LDL-C' $=$ LDL-C + Lp(a)-C: Implications of achieved ultra-low LDL-C levels in the proprotein convertase subtilisin/kexin type 9 era of potent LDL-C lowering. Curr. Opin. Lipidol. 2015, 26, 169-178. [CrossRef]

160. Langlois, M.R.; Nordestgaard, B.G.; Langsted, A.; Chapman, M.J.; Aakre, K.M.; Baum, H.; Boren, J.; Bruckert, E.; Catapano, A.; Cobbaert, C.; et al. Quantifying atherogenic lipoproteins for lipid-lowering strategies: Consensus-based recommendations from EAS and EFLM. Clin. Chem. Lab. Med. 2020, 58, 496-517. [CrossRef]

161. Nordestgaard, B.G.; Langlois, M.R.; Langsted, A.; Chapman, M.J.; Aakre, K.M.; Baum, H.; Boren, J.; Bruckert, E.; Catapano, A.; Cobbaert, C.; et al. Quantifying atherogenic lipoproteins for lipid-lowering strategies: Consensus-based recommendations from EAS and EFLM. Atherosclerosis 2020, 294, 46-61. [CrossRef]

(C) 2020 by the authors. Licensee MDPI, Basel, Switzerland. This article is an open access article distributed under the terms and conditions of the Creative Commons Attribution (CC BY) license (http://creativecommons.org/licenses/by/4.0/). 